\title{
Environmental relevant levels of the cytotoxic drug cyclophosphamide produce harmful effects in the polychaete Nereis diversicolor
}

\author{
T.G. Fonseca ${ }^{\mathrm{a}, \mathrm{b}}$, M. Auguste ${ }^{\mathrm{a}}$, F. Ribeiro ${ }^{\mathrm{a}}$, C. Cardoso ${ }^{\mathrm{a}}$, N.C. Mestre ${ }^{\mathrm{a}}$, D.M.S. Abessa ${ }^{\mathrm{b}}$, M.J. Bebianno ${ }^{\mathrm{a}, *}$ \\ a CIMA, Centre for Marine and Environmental Research, University of Algarve, Campus Gambelas, 8005-135 Faro, Portugal \\ ${ }^{\mathrm{b}}$ NEPEA, Núcleo de Estudos em Poluição e Ecotoxicologia. Aquática, Universidade Estadual Paulista - UNESP, Campus Experimental do Litoral Paulista, Praça Infante Dom Henrique, s/n, 11330-900 \\ São Vicente, SP, Brazil
}

\section{H I G H L I G H T S}

- Nereis diversicolor exposed to the cyclophosphamide (CP) at trace levels in seawater.

- Burrowing behavior showed a nonmonotonic profile over increasing $\mathrm{CP}$ levels.

- Oxidative stress was observed at higher $\mathrm{CP}$ concentrations.

- Genotoxicity was detected as a result of prodrug activation.

- $N$. diversicolor showed to metabolize the drug according to its mode of action.

\section{A R T I C L E I N F O}

\section{Article history:}

Received 18 January 2018

Received in revised form 23 April 2018

Accepted 24 April 2018

Available online 1 May 2018

Editor: Daniel Wunderlin

\section{Keywords:}

Anticancer drugs

Cyclophosphamide

Sediments

Polychaetes

Oxidative stress

Genotoxicity
G R A P H I C A L A B S T R A C T

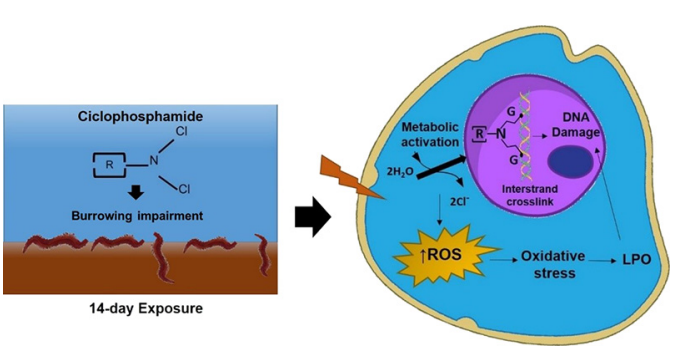

A B S T R A C T

Cytotoxic drugs applied in chemotherapy enter the aquatic environment after patient's metabolism and excretion, in both main compounds and their respective metabolites. The increased consumption and discharge of these drugs raise concern on the genotoxic burden to non-target aquatic species, due to their unselective action on DNA. Settlement and adsorption of cytotoxic drugs to aquatic sediments pose risks to benthic species through chronic exposure. The aim of the present study was to assess the effects induced by the anticancer drug cyclophosphamide $(\mathrm{CP})$ on the polychaete Nereis diversicolor, after 14 days of exposure to environmental relevant concentrations $\left(10,100,500\right.$ and $\left.1000 \mathrm{ng} \mathrm{L}^{-1}\right)$. Burrowing impairment, neurotoxicity (Acetylcholinesterase - AChE activity), oxidative stress (superoxide dismutase - SOD; catalase - CAT; glutathione peroxidases - GPXs activities), biotransformation (glutathione-S-transferases - GST), oxidative damage (lipid peroxidation - LPO) and genotoxicity (DNA damage) were assessed. Burrowing impairments were higher at the lowest CP concentrations tested. The higher $\mathrm{CP}$ levels tested (500 and $1000 \mathrm{ng} \mathrm{L}^{-1}$ ) induced a significant inhibition on the enzymatic antioxidant system (SOD, GPx) and on GST activity. DNA damage was also significant at these concentrations as an outcome of CP metabolism, and high levels of oxidative damage occurred. The results showed that the prodrug $\mathrm{CP}$ was metabolically activated in the benthic biological model $N$. diversicolor. In addition to the potential cytotoxic impact likely to be caused in aquatic species with similar metabolism, $N$. diversicolor proved to be reliable and vulnerable to the cytotoxic mode of action of $\mathrm{CP}$, even at the lower doses.

(c) 2018 Elsevier B.V. All rights reserved.

\footnotetext{
* Corresponding author.

E-mail address: mbebian@ualg.pt (M.J. Bebianno).
}

\section{Introduction}

Anticancer drugs (or antineoplastic drugs) are a group of pharmaceuticals routinely and widely administered in chemotherapy all over the world, whether individually or in combination with other cytotoxic 
agents. In 2012, 14.1 million new cancer cases were reported around the world, and the World Health Organization (WHO) estimates an enhancement of $57 \%$ of new cases until 2030 (WHO, 2014). Besides the subsequent increase of cytotoxic prescriptions, approximately $80 \%$ of oncology patients receive treatment at oncology wards and go home after drug administration (i.e. out-patients). Additionally to conventional elimination into hospital sewage systems, metabolites and unchanged fractions of the administered drug are excreted through urban effluents, following to municipal wastewater treatment plants (WWTPs), where elimination of these substances is incomplete (Johnson et al., 2008; Kosjek and Heath, 2011). Furthermore, these chemicals may also be released directly to the water bodies, in regions not properly attended by sewage collection and treatment systems (Abessa et al., 2005; Pessatti et al., 2016).

Consequently, anticancer drugs are detected at low levels (ng to $\mu \mathrm{g} \cdot \mathrm{L}^{-1}$ range) in aquatic systems (Crane et al., 2006; Johnson et al., 2008; Kosjek and Heath, 2011; Booker et al., 2014; Mater et al., 2014) and long-term exposure to non-target species has led to the concern of genotoxic burden of cytotoxic drugs to aquatic species (StegerHartmann and Kiimmerer, 1996; Steger-Hartmann et al., 1997; Buerge et al., 2006; Ferrando-Climent et al., 2014). In general, the conventional chemotherapy drugs act directly on the DNA double strand, in order to avoid the synthesis and proliferation of tumor cells (Farber, 1973). Such covalent interaction primarily alters the DNA helical structure, influences the binding of chromatin protein and induces DNA strand breaks, subsequently producing genotoxic effects, followed by the death of the tumor cells (Harris, 1976; Ou and Lien, 1985). However, once these "targets" are not specific drivers of cancer cells, normal growing cells are also affected through the same mode of action (MoA) by which they may be killed or left unrepaired, followed by genomic instability with neoplastic transformation and eventual carcinogenic mutations (Johnson et al., 2008; Kosjek and Heath, 2011; Ferrando-Climent et al., 2014). Acting unselectively on DNA, it has been hypothesized that anticancer drugs may harm all eukaryotic organisms by cytotoxic, genotoxic, mutagenic and carcinogenic effects (Johnson et al., 2008; Vyas et al., 2014). The biological risk posed by these anticancer molecules and their metabolites in aquatic species is not well elucidated (Mater et al., 2014), with few data on acute and chronic ecotoxicological assessments in algae Tetrahymena pyriformis (Bonnet et al., 2003), Pseudomonas putida (Zounková et al., 2007) and Pseudokirchneriella subcapitata (Zounková et al., 2007; Brezovsek et al., 2014; Česen et al., 2016); polychaete Nereis diversicolor (Fonseca et al., 2017); bivalve mollusc Mytilus galloprovincialis (Trombini et al., 2016); cladocera crustaceans Daphnia pulex (DellaGreca et al., 2007; Borgatta et al., 2015, 2016), D. magna (Zounková et al., 2007; Parrella et al., 2014a, 2014b, 2015) and Ceriodaphnia dubia (DellaGreca et al., 2007; Parrella et al., 2014a, 2014b, 2015); crustacean amphipod Ampelisca brevicornis (Moreira et al., 2016); and the fishes Danio rerio (Kovacs et al., 2015), Pimephales promelas (Winter et al., 2007) and Oryzias latipes (Sun et al., 2011). Limited information exists regarding Environmental risk assessment (ERA) for anticancer drugs. ERA guidelines are assigned only for newly authorized pharmaceuticals (since 2006) and do not include molecules prone to cause genotoxicity impairments in aquatic ecosystems (Johnson et al., 2008; Aguirre-Martínez et al., 2016).
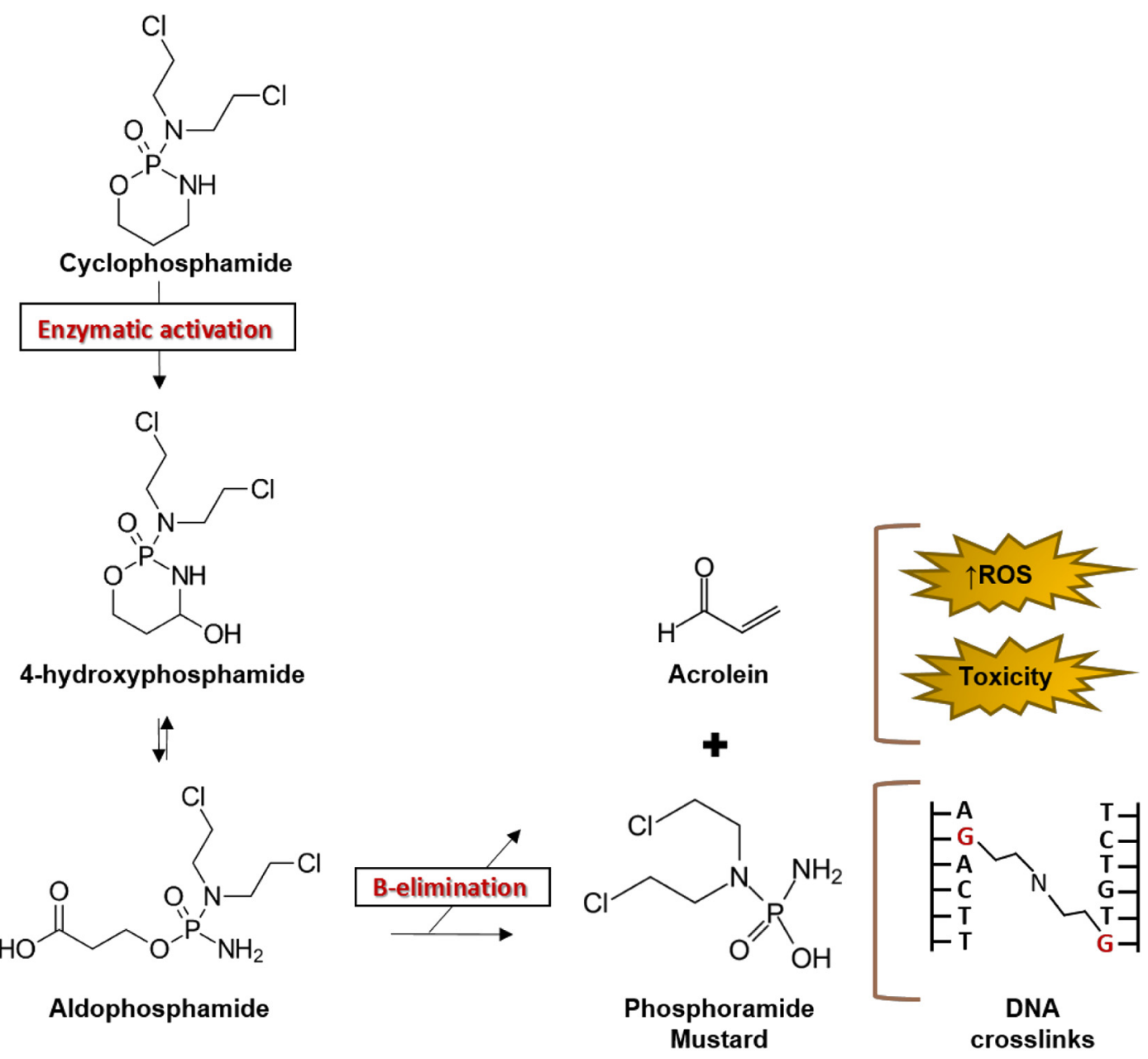

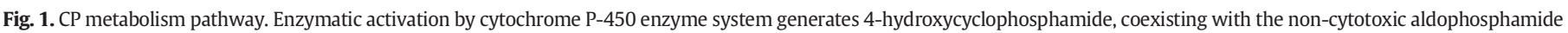
metabolite. It decomposes into acrolein, that is toxic, and the DNA-binding phosphoramide mustard. 
Cyclophosphamide (CP) is one of the oldest and most frequently prescribed cytotoxic and alkylating agent used in cancer treatment, approved since 1960's (Gilard et al., 1994; Buerge et al., 2006; Česen et al., 2015). It consists of a phosphoramide ring linked to a bifunctional moiety containing two chloro-ethyl groups. $\mathrm{CP}$ is a prodrug and its activation consists in the oxidation by cytochrome P450 mixed function oxidase to form 4-hydroxy-CP (4-OHCP), undergoing subsequent transformations to yield the major cytotoxic species, the phosphoramide mustard (PAM) and acrolein (Fig. 1).

After administration, around $80 \%$ of the dose is excreted as metabolites, which accounts for substantial amounts of metabolites disposed into sewage systems (Bagley et al., 1973; Steger-Hartmann and Kiimmerer, 1996). In the absence of metabolic activating systems, CP fails to bind to DNA and its genotoxic activity is prevented. Even without metabolic activation by S9-rat extracted fraction, the parental drug $\mathrm{CP}$ caused mutagenic effects in the bacteria Escherichia coli and Salmonella typhimurium, and in the cyanobacteria Synechococcus leopoliensis ( $320 \mathrm{mg} \mathrm{L}^{-1}$ ) (Česen et al., 2016), indicating that not only the metabolites are involved in cellular impairments (Benedict et al., 1977; Mohn and Ellenberger, 1976; Balbinder et al., 1981; Winckler et al., 1984). Research concerning $\mathrm{CP}$ and its ecotoxicological effects in aquatic organisms is scarce and do not comprise exposure routes by which species would uptake the drug. Data available addresses the drug as a toxic positive control in in vivo short term bioassays assessing mortality, immobilization, growth and reproduction inhibition, larval development and genotoxicity as end-points with CP levels far from environmental relevant concentrations (Matsumoto and Cólus, 2000).

Considering that most of cytotoxic drugs are highly polar, with low $K_{\text {ow }}$, the fraction of drugs adsorbed into sewage sludge could be neglected and distribution is assumed to be mainly in the water column (Kosjek and Heath, 2011; Seira et al., 2016). Negligible biodegradability, volatilization and adsorption of $\mathrm{CP}$ to biosolids confirms this assumption (Buerge et al., 2006; Steger-Hartmann and Kiimmerer, 1996; Steger-Hartmann et al., 1997). However, pharmaceuticals are multifunctional ionizable compounds and conventional partitioning models are not suited for a straightforward prediction of their environmental fate (Kwon and Armbrust, 2008). Once in the aquatic environment, hydrophobic interactions providing adsorbance of polar compounds to particulates may not be disregarded, especially for organic cations, which are formed during intra-molecular cyclizations for cytotoxic drugs activation (e.g. CP aziridinium cation) (Williams et al., 2000; Emadi et al., 2009; Kosjek and Heath, 2011). Therefore, specific transformations in coastal environments may allow their adsorption, transference and persistence to the sediments (Kosjek and Heath, 2011; Maranho et al., 2014; Moreno-González et al., 2015).

Sediments are the ultimate sink for contaminants in the marine environment, posing benthic species at risk through chronic exposure and bioaccumulation (Buruaem et al., 2012; Araujo et al., 2013; Vethaak et al., 2016). Nevertheless, aquatic ecotoxicological assessment of anticancer drugs involving sediments is lacking (Fonseca et al., 2017). In addition, to the best of our knowledge, only two studies exist on the occurrence of anticancer drugs in river sediments, where levels ranged below the detection limit (Zuccato et al., 2000) and $391 \mathrm{ng} \mathrm{kg}{ }^{-1}$ (bicalutamide), $392 \mathrm{ng} \mathrm{kg}^{-1}$ (doxifluridine), and $250 \mathrm{ng} \mathrm{kg}^{-1}$ (tamoxifen) (Azuma et al., 2017). So far, no screening approach was directed to the coastal environment. The levels of CP detected in hospital effluents, WWTPs influents and effluents, surface waters and sediments are indicated in Table 1. Data suggests that this drug and its metabolites are likely to contribute to overall toxicity in receiving waters (Kiffmeyer et al., 1998; Yasunaga et al., 2006; Kosjek and Heath, 2011; Česen et al., 2016).

Polychaetes are widely used in marine environmental health assessment due to their ecological key role in benthic dynamics (Solé et al., 2009), and their rapid and easy response to disturbances induced by different stressors (Sivadas et al., 2010; Cong et al., 2011; Buffet et al., 2014; Maranho et al., 2015). The species Nereis (Hediste) diversicolor is highly recommended for ecotoxicological assessment regarding their physiological and biochemical responses after exposure to different classes of pharmaceuticals (e.g. anti-inflammatory; oral contraceptive; anticonvulsant; antidepressant drugs) (Aguirre-Martínez et al., 2013; Maranho et al., 2014, 2015; Fonseca et al., 2017; Pires et al., 2016a). Exposure to the cytotoxic drug cisplatin, at trace concentrations $\left(0.1 ; 10\right.$ and $\left.100 \mathrm{ng} \mathrm{Pt} \mathrm{L}{ }^{-1}\right)$ in seawater, caused behavioural and biochemical impairments in this species, after 14 days of exposure (Fonseca et al., 2017).

The aim of the present study is to assess the effects induced by the anticancer drug $\mathrm{CP}$ in the polychaete $N$. diversicolor, exposed to a

Table 1

Concentrations of $\mathrm{CP}$ in water (ng L $\mathrm{L}^{-1}$ ) and sediments $\left(\mathrm{ng} \mathrm{g}^{-1}\right)$.

\begin{tabular}{|c|c|c|c|c|c|c|c|c|}
\hline \multirow[t]{2}{*}{ Study area } & \multirow[t]{2}{*}{ Hospital effluent } & \multirow[t]{2}{*}{ STP influent } & \multirow[t]{2}{*}{ STP effluent } & \multicolumn{2}{|c|}{ Surface water } & \multirow[t]{2}{*}{ River sediments } & \multirow[t]{2}{*}{ Detection method } & \multirow[t]{2}{*}{ Reference } \\
\hline & & & & Upstream & Downstream & & & \\
\hline Australia & - & - & $<125$ & - & $<100$ & - & SPE; LC-MS/MS (ESI) & Busetti et al. (2009) \\
\hline Canada & & $<4-22$ & $<4-21$ & & & - & SPE; LC-MS/MS (ESI) & Rabii et al. (2014) \\
\hline China & $6-2000$ & - & - & - & - & - & SPE; UPLC-MS/MS (ESI) & Yin et al. (2010) \\
\hline Thailand & - & - & - & & 1907 & - & SPE; HPLC-MS/MS & Usawanuwat et al. (2014) \\
\hline England & - & - & $0.19-0.37$ & - & - & - & SPE; LC-MS/MS (ESI) & Llewellyn et al. (2011) \\
\hline Germany & $19-4500$ & $<6-143$ & $<6-17$ & - & - & - & SPE; GC-MS (EI) & Steger-Hartmann et al. (1997) \\
\hline Germany & 146 & - & - & - & - & - & SPE; GC-MS (EI) & Steger-Hartmann and Kiimmerer (1996) \\
\hline Germany & - & - & nd & - & nd & - & LC-MS/MS (ESI) & Ternes (1998) \\
\hline Italy & - & - & - & - & nd ( 8 rivers) & - & SPE; HPLC-MS/MS (ESI) & Calamari et al. (2003) \\
\hline Italy & - & - & nd - 9 & - & - & - & SPE; HPLC-MS/MS (ESI) & Castiglioni et al. (2005) \\
\hline Italy & - & - & 0.6 & - & nd & - & SPE; HPLC-MS/MS & Zuccato et al. (2005) \\
\hline Italy & - & - & - & - & $2.2-10.1$ & $<12$ & SPE; HPLC-MS/MS & Zuccato et al. (2000) \\
\hline Japan & - & - & - & - & nd & nd & SPE; UPLC-MS/MS & Azuma et al. (2017) \\
\hline Norway & $<2-21$ & $<2$ & $<2$ & - & - & - & SPE; LC-TOF/MS (ESI) & Thomas et al. (2007) \\
\hline Romania & - & - & - & - & $<30-64.8$ & - & SPE; GC-MS (EI) & Moldovan (2006) \\
\hline Spain & $<1.1-43$ & $8-26$ & $7-25$ & $<0.9$ & $<0.9-20$ & - & SPE; UPLC QqLiT & Ferrando-Climent et al. (2014) \\
\hline Spain & - & - & - & - & $<3$ & - & SPE; HPLC-MS/MS & Valcárcel et al. (2011) \\
\hline Spain & & & & & $7.8-13.7$ & - & SPE; LC-MS (ESI) & Franquet-Griell et al. (2017) \\
\hline Spain & 5,73 & $<3.1-13,100$ & $<3.1$ & - & - & - & SPE; LC-MS (ESI) & Gómez-Canela et al. (2012) \\
\hline Spain & - & $<2.1$ & $<2.3$ & - & $<1.7$ & - & SPE; HPLC-MS/MS (ESI) & Martín et al. (2011) \\
\hline Spain & - & nd & nd & - & - & - & SPE; HPLC-MS/MS (ESI) & Martín et al. (2014) \\
\hline Spain & & nd -43.8 & nd -25 & - & - & - & SPE; LC-MS/MS (ESI) & Negreira et al. (2014) \\
\hline Slovenia & $14-22,000$ & $19-27$ & 17 & - & - & - & SPE; GC-MS (EI) & Česen et al. (2015) \\
\hline Switzerland & - & $2-11$ & $\sim 2-10$ & - & $0.15-0.17$ & - & SPE; LC-MS/MS (ESI) & Buerge et al. (2006) \\
\hline Switzerland & 0.161 & - & - & - & - & - & SPE; HPLC-MS/MS (ESI) & Kovalova et al. (2012) \\
\hline
\end{tabular}

- STP: sewage treatment plant. 
range of environmental relevant concentrations of $\mathrm{CP}$ detected in water compartments. For this purpose, the following biomarkers were assessed (1) behavioural impairment (burrowing kinetic impairment), (2) neurotoxicity (Acetylcholinesterase - AChE activity), (3) oxidative stress (superoxide dismutase - SOD; catalase - CAT; glutathione peroxidases - GPXs), (4) Phase II conjugation reaction (glutathione-Stranferases - GST activity), (5) oxidative damage (Lipid peroxidation LPO) and (6) genotoxicity (DNA damage), after exposure for 14 days to a contaminated water-sediment system.

\section{Materials and methods}

\subsection{Chemicals}

Cyclophosphamide monohydrate (Cytoxan) (CAS 0768) was purchased from Sigma-Aldrich (Portugal). For safety handling of the cytotoxic drug, experimental work was performed using class II biological safety cabinet, with appropriate clothing (open-back, impervious chemotherapy protection gown, double powder-free latex gloves and safety goggles). CP stock solution ( $\left.40 \mathrm{mg} \mathrm{L}^{-1}\right)$ was diluted in ultrapure Milli-Q water to prepare test solutions.

\subsection{Experimental setup}

Sediments and specimens of $N$. diversicolor were handpicked during summer, at low tide at the intertidal estuarine mudflat in Mira River estuary (Vila Nova de Milfontes), located in the Southwest coast of Portugal ( $37.729031 \mathrm{~N},-8.751585 \mathrm{~W}$ ). The site is considered undisturbed and was used as a reference site for sediment quality assessment (Ferreira et al., 2003; Moreira et al., 2006; Fonseca et al., 2017). Sediments were mainly composed of silt and clay (73\% of particles $<63$ $\mu \mathrm{m})$, with a organic matter content of $7.8 \%$. Animals were transported alive to the laboratory with sediments and water from the site of origin. The organisms were acclimated for 5 days in aerated aquaria filled with natural filtered seawater (salinity 35) from the Ria Formosa lagoon (Faro, Portugal) and sediments from the sampling site.

The sediments were wet-sieved through a 2-mm mesh for removal of large debris and other living organisms, followed by drying at $80{ }^{\circ} \mathrm{C}$ (Thain and Bifield, 2001; ASTM, 2009; Maranho et al., 2014), to remove volatile compounds and water. Sediments were then re-hydrated with the same amount of water (w.w./d.w.). Dried aliquots of the sediments were used to determine grain size distribution by the method proposed by Royse (1970). Organic matter content was determined by loss on ignition $\left(550^{\circ} \mathrm{C}\right.$, for $5 \mathrm{~h}$ ), as described by Gross (1971).

The 14-day bioassay was carried out in 20-L glass aquaria, with a proportion of 1:4 sediment/seawater (Faro, Ria Formosa), under constant aeration, controlled temperature $\left(19 \pm 2{ }^{\circ} \mathrm{C}\right)$, salinity $(35 \pm 1.8)$ and light period (12:12 h). Each treatment was performed in triplicate, including seawater controls (day 0: CT0; day 14 CT14), solvent control (0.001\% DMSO) and CP at a range of concentrations based on reported levels in the environment (Table 1). Polychaetes were divided into groups of 75 organisms per treatment in a triplicate design (25 per aquarium). Over the 14 days of exposure, water was renewed every $48 \mathrm{~h}$ avoiding sediment resuspension, with redosing of the drug in the water phase $\left(0,10 ; 100 ; 500\right.$ and $\left.1000 \mathrm{ng} \mathrm{L}^{-1}\right)$ in order to simulate the input of pharmaceuticals in aquatic system. After 14 days of exposure, all animals were collected. Those used in the burrowing and comet assays were immediately handled for respective analysis, while those regarding biochemical end-points were rinsed with clean seawater and stored at $-80{ }^{\circ} \mathrm{C}$ until further use.

\subsection{Burrowing assay}

Worms of control conditions (day 0: CT0; day 14: CT14) and those exposed to the different $\mathrm{CP}$ concentrations were submitted to a burrowing test according to Bonnard et al. (2009). Fifteen animals of each treatment were carefully placed individually in $150 \mathrm{~mL}$-plastic containers, filled with natural seawater and $5 \mathrm{~cm}$ of sediments. Over a period of 30 -minute, the position of the polychaetes was recorded every two minutes, to assess the time for fully burrowing. The results are expressed as the percentage (\%) of unburrowed specimens, over time (min).

\subsection{Biochemical analysis}

\subsubsection{Neurotoxicity}

Polychaetes ( 2 specimens per aquaria, in triplicate; total of 6 organisms per treatment) were individually homogenized in $100 \mathrm{mM}$ Tris$\mathrm{HCl}$ buffer ( $\mathrm{pH} 8.0$ ) and $0.1 \%$ Triton. The homogenates were centrifuged at $12,000 \mathrm{~g}$, for $30 \mathrm{~min}$, at $4{ }^{\circ} \mathrm{C}$, and further separated in aliquots for total protein determination (Bradford, 1976) and AChE activity analysis (Ellman et al., 1961). AChE activity was measured through the increase of the absorbance of the yellow compound resulting from the production of 5-mercapto-2-nitrobenzoate $\left(\varepsilon=13.6 \mathrm{mM}^{-1} \mathrm{~cm}^{-1}\right)$ formed by the reaction of thiocholine, a product of acetylcholine cleavage by AChE with 5,5-Dithiobis(2-nitrobenzoic acid) (DTNB), at $405 \mathrm{~nm}$ (Ellman et al., 1961; Colovic et al., 2013). AChE activity is expressed as ATC $\cdot \mathrm{min}^{-1} \mathrm{mg}^{-1}$ protein.

\subsubsection{Tissue preparation for enzyme activities analysis}

Whole organisms ( 2 specimens per aquaria, in triplicate; total of 6 organisms per treatment), were homogenized in $20 \mathrm{mM}$ Tris- $\mathrm{HCl}$ buffer (0.5 M sucrose, 0,075 M KCl, 1 mM DTT, 1 mM EDTA, pH 7.6), according to the protocol described by Geret et al. (2002). The homogenates were centrifuged at $500 \mathrm{~g}$, for $15 \mathrm{~min}$, at $4{ }^{\circ} \mathrm{C}$, and the supernatants obtained centrifuged again $\left(12,000 \mathrm{~g}, 45 \mathrm{~min}, 4^{\circ} \mathrm{C}\right)$. Aliquots $(150 \mu \mathrm{L})$ of the cytosolic fraction were separated for determination of each antioxidant enzyme activity (SOD, CAT, GPX) and biotransformation (GST). In addition, total proteins concentrations ( $\mathrm{mg}_{\text {protein }} \mathrm{g}^{-1}$ tissue) were determined following the method described by Bradford (1976), adapted for microplate reader using bovine serum albumin (BSA) as a standard.

\subsubsection{Antioxidant enzymes activities}

SOD activity was assessed by measuring the decrease of absorbance of the substrate cytochrome-c by xanthine oxidase/hypoxanthine system, at $550 \mathrm{~nm}$ (McCord and Fridovich, 1969), and the results are expressed as $\mathrm{U} \mathrm{mg}^{-1}$ protein. CAT activity was determined spectrophotometrically by measuring the decrease of absorbance at $240 \mathrm{~nm}$ (Greenwald, 1985). GPX activity was measured at $340 \mathrm{~nm}$ by using cumene hydroperoxide and $\mathrm{H}_{2} \mathrm{O}_{2}$ as substrates for T-GPx and Se-GPx, respectively (adapted from Lawrence and Burk, 1976). The activity of CAT, Se- and T-GPx are expressed in nmol $\mathrm{min}^{-1} \mathrm{mg}^{-1}$ protein.

\subsubsection{Biotransformation}

GST activity was measured in the cytosolic fraction by the conjugation of $0.2 \mathrm{mM}$ reduced glutathione (GSH) with $0.2 \mathrm{mM} \mathrm{CDNB}$ (molar coefficient of extinction $=0.6 \mathrm{mM}^{-1} \mathrm{~cm}^{-1}$ ) in a reaction mixture of $0.2 \mathrm{M}$ $\mathrm{KH}_{2} \mathrm{PO}_{4} / \mathrm{K}_{2} \mathrm{PO}_{4}$ buffer ( $\mathrm{pH} 7.9$ ), at $340 \mathrm{~nm}$ (adapted from Habig et al.,

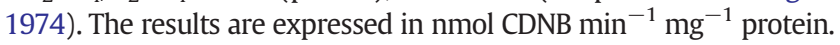

\subsubsection{Oxidative damage}

LPO was determined in whole organisms (2 specimens per aquaria, in triplicate; total of 6 organisms per treatment), by the absorbance of malondialdehyde (MDA) and 4-hydroxyalkenals (4-HNE) concentrations, at $540 \mathrm{~nm}$ (adapted from Erdelmeier et al., 1998). LPO is expressed in nmol MDA + 4-HNE $\mathrm{mg}^{-1}$ protein.

\subsection{Genotoxicity assay}

DNA damage was assessed by the alkaline Comet assay, adapted from Singh et al. (1988) and described by Gomes et al. (2013). Slides were previously cleaned in alcohol/ether and coated with $0.65 \%$ normal melting point agarose (NMA) in Tris-acetate EDTA. Coelomocytes, 
present in the coelomic fluid of $N$. diversicolor ( 5 specimens per aquaria, in triplicate; total of 15 organisms per treatment), were extracted from the posterior region of the polychaete body into $20 \mu \mathrm{L}$ of PBS buffer in a $0.5 \mathrm{~mL}$-syringe fitted with hypodermic needle, based on the procedure described by Fonseca et al. (2017). The mixture was centrifuged at $835 \mathrm{~g}\left(3 \mathrm{~min}, 4^{\circ} \mathrm{C}\right)$ and the pellet suspended in $0.65 \%$ low melting point agarose (LMA, in Kenny's salt solution; $0.4 \mathrm{M} \mathrm{NaCl}, 9 \mathrm{mM} \mathrm{KCl}$, $0.7 \mathrm{mM} \mathrm{KH}_{2} \mathrm{PO}_{4}, 2 \mathrm{Mm} \mathrm{NaHCO}_{3}, 1000 \mathrm{~mL}$ Milli-Q water) and casted on the microscope slides. Subsequently, slides were immersed in a lysis buffer (100 mM EDTA, $2.5 \mathrm{M} \mathrm{NaCl}, 10 \mathrm{mM}$ Tris, $1 \%$ Triton X-100, $10 \%$ Dimethylsulfoxide, $1 \%$ Sarcosil, $\mathrm{pH} 10,4{ }^{\circ} \mathrm{C}$ ), over $1 \mathrm{~h}$, for the diffusion of cellular components and DNA immobilization in agarose. Slides were then placed in electrophoresis chamber, embedded with buffer (300 mM NaOH, $1 \mathrm{mM}$ EDTA, adjusted at $\mathrm{pH} 13,4{ }^{\circ} \mathrm{C}$ ) and left for $15 \mathrm{~min}$ to permit DNA unwinding. The electrophoresis was performed at $25 \mathrm{~V}$ and $300 \mathrm{~mA}$, over $5 \mathrm{~min}$. Afterwards, slides were neutralized with appropriate buffer $(0.4 \mathrm{mM}$ Tris, $\mathrm{pH} 7.5)$, rinsed with distilled water and left to dry overnight.

Slides were analysed with an optical fluorescence microscope Axiovert S100 (total magnification of $\times 400$ ), coupled with a camera, with an aid of 4,6-diamidino-2-phenylindole (DAPI, $1 \mathrm{mg} \mathrm{mL}^{-1}$ ). Image analysis was made with the software Komet 5.5 (Kinetic Imaging Ltd.) by classifying 50 randomly chosen cells from each slide. The amount of DNA in the comet tail (DNA tail \%) was used as an endpoint and results are expressed as mean \pm SEM.

\subsection{Statistical analysis}

Data was tested for normality (Shapiro-Wilk test) and homogeneity of variance (Levene's test) in order to determine whether they satisfy the assumptions associated with parametric tests. One-way analysis of variance (ANOVA) or the non-parametric Kruskal-Wallis were applied and Tukey's or Dunn's post-hoc tests performed to compare treatment effects. Results were significant when $p<0.05$. Burrowing behavioural data was analysed by linear regression. Principal Component Analysis (PCA) were applied to evaluate the relationship among biomarkers responses and between pharmaceuticals levels. Statistical analysis was carried out using the Statistica 8.0 software (Statsoft Inc., 2007, USA).

\section{Results}

\subsection{Behavioural assay}

Results of burrowing assessment are indicated in Fig. 2. Slopes of trend lines depicting by linear regression analysis showed significant statistical differences between all treatments $(p<0.05)$. Both control

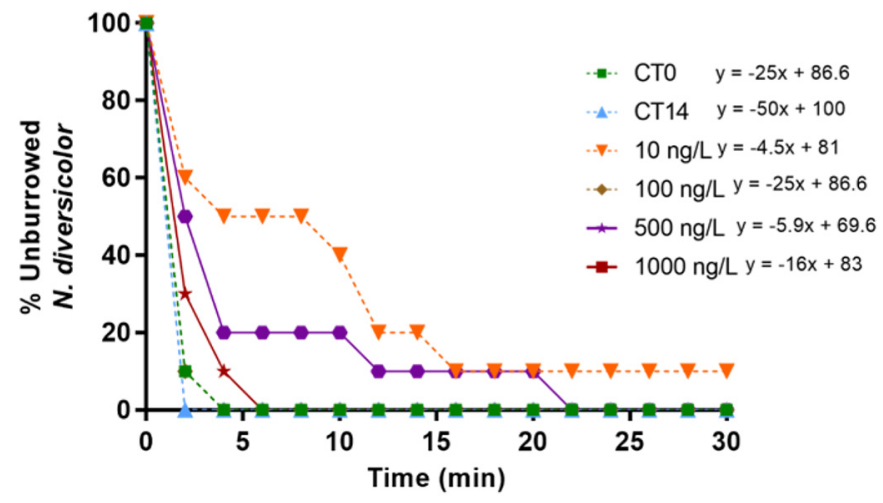

Fig. 2. Burrowing behaviour of $N$. diversicolor from control conditions (day 0: CT0; day 14: CT14) and those exposed to CP-contaminated systems (10, 100, 500 and $1000 \mathrm{ng} \mathrm{L}^{-1}$ ), expressed as percentage of unburrowed organisms over time (lines with symbols). Continuous lines represent least-square best-fit regression lines, with respective equations. conditions (CT0 and CT14) indicate similar trend, as well as for animals exposed to the concentration of $100 \mathrm{ng} \mathrm{L}^{-1}$, that was entirely overlapped by CTO. Perturbation in burrowing, however, was higher with the decrease of cyclophosphamide levels. Polychaetes exposed to $1000 \mathrm{ng} \mathrm{L}^{-1}$ were fully buried after the first $5 \mathrm{~min}$, whereas at $500 \mathrm{ng} \mathrm{L^{-1 }}$, animals lasted 20 min at surface until complete burrowing while among those exposed to $10 \mathrm{ng} \mathrm{L}^{-1}$ not all the animals were buried.

\subsection{Biochemical analysis}

\subsubsection{Neurotoxicity}

AChE activity did not change between controls over time $(p>0.05)$. A slight decreasing in AChE activity was observed in polychaetes exposed to the lowest $\mathrm{CP}$ concentrations $\left(10 \mathrm{ng} \mathrm{L}^{-1}\right)$, although not significant $(p>0.05)$. With the increase of CP concentrations AChE activity was similar to the controls $(p>0.05)$ (Fig. 3 ).

\subsubsection{Antioxidant and biotransformation enzymes}

Antioxidant enzymes activities were similar between controls over time $(p>0.05)$. Despite no significant statistical differences between $\mathrm{CP}$-treatments and controls, it was observed an increase in SOD activity in ragworms exposed to 10 and $100 \mathrm{ng} \mathrm{L}^{-1}$ of $\mathrm{CP}$, followed by an inhibition in organisms exposed at the higher $\mathrm{CP}$ levels (i.e. 500 and $1000 \mathrm{ng} \mathrm{L}^{-1}$ ) (Fig. 4A). A significant 2-fold increase in CAT activity was detected in worms exposed to concentrations of 10 and $500 \mathrm{ng} \mathrm{L}^{-1}$ (Fig. 4B), whereas no significant changes were observed for GPx Se-dependent activity with CP increasing levels $(p>0.05)$. On the other hand, a clear decreasing trend in T-GPx activity was detected with increasing $\mathrm{CP}$ concentrations, significantly different from controls only in polychaetes exposed to 500 and $1000 \mathrm{ng} \mathrm{L}^{-1}(p<0.05)$. Likewise, GST activity decreased with the increasing CP concentrations, significant at 100,500 and $1000 \mathrm{ng} \mathrm{L}^{-1}(p<0.05)$ (Fig. 5).

\subsubsection{Oxidative damage}

An increase of oxidative damage was clear in polychaetes with the increase of CP concentrations with significant differences at 500 and $1000 \mathrm{ng} \mathrm{L}^{-1}$ compared to controls $(p<0.05)$ (Fig. 6).

\subsection{Genotoxicity}

Data of DNA tail (\%) and DNA damage grade after 14 days of exposure are presented in Table 2. Despite all polychaetes exposed to CP treatments indicated DNA damage compared to its respective control

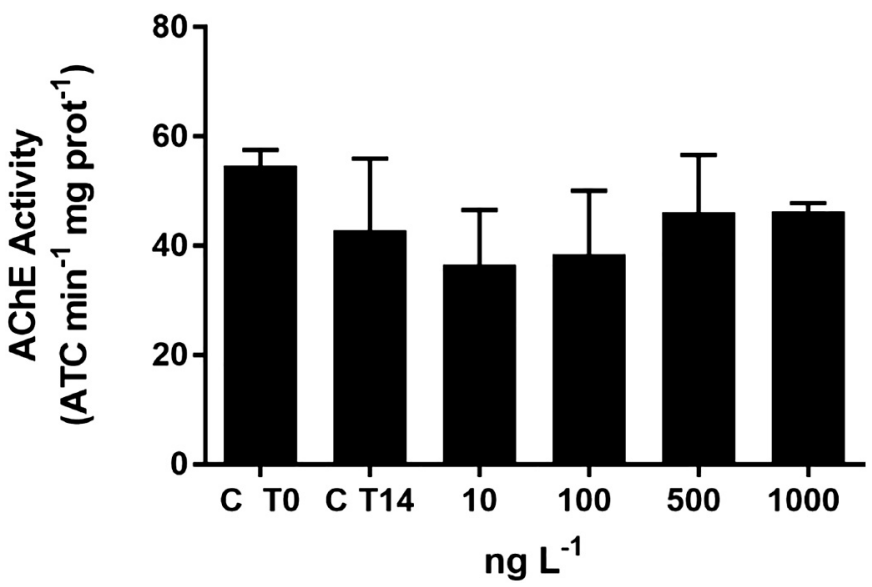

Fig. 3. AChE activity (mean \pm S.D.) (ATC $\cdot \mathrm{min}^{-1} \cdot \mathrm{mg}^{-1}$ protein) in $\mathrm{N}$. diversicolor unexposed (CT 0 and CT 14) and exposed to CP $\left(10,100,500\right.$ and $\left.1000 \mathrm{ng} \mathrm{L}^{-1}\right)$ for 14 days. Absence of letters indicates no significant differences among treatments (Kruskal-Wallis, $p>0.05$ ). 

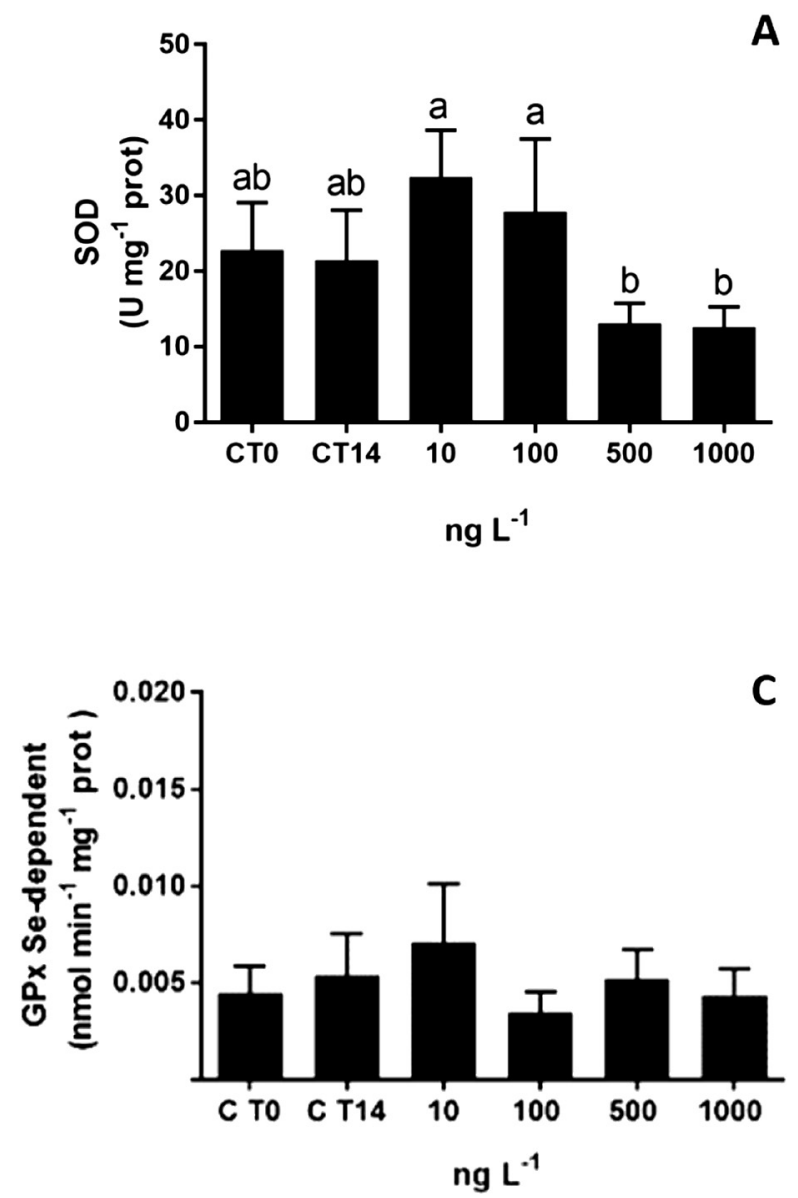
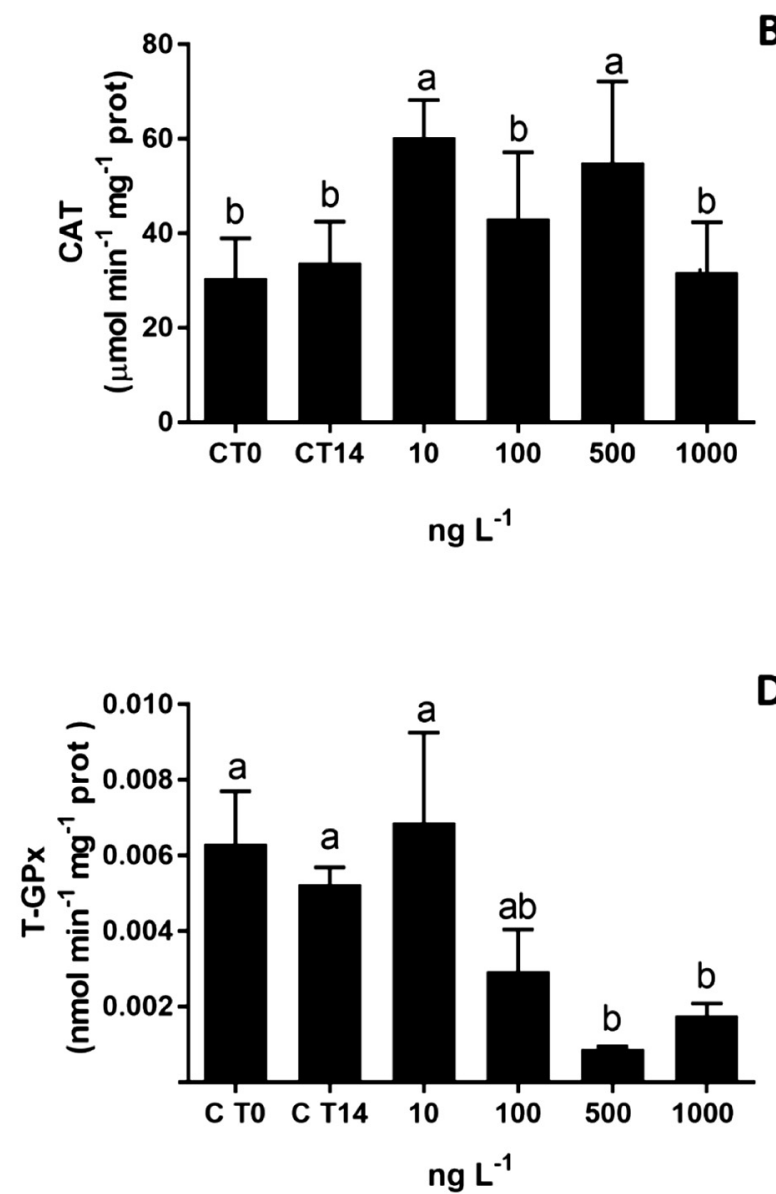

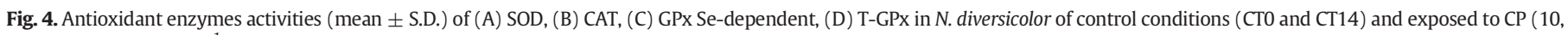

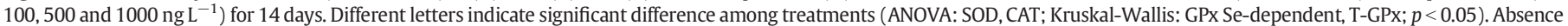
of letters indicates no significant differences among treatments $(p>0.05)$.

$(p<0.05)$, the grade of impairment was always between minimal to mid damage.

\subsection{Principal Component Analysis (PCA)}

PCA results indicate a two-dimensional pattern explaining $81.4 \%$ of the total variance ( $\mathrm{PC} 1=46.3 \%$; $\mathrm{PC} 2=36.2 \%$ ) (Fig. 7 ). Overall,

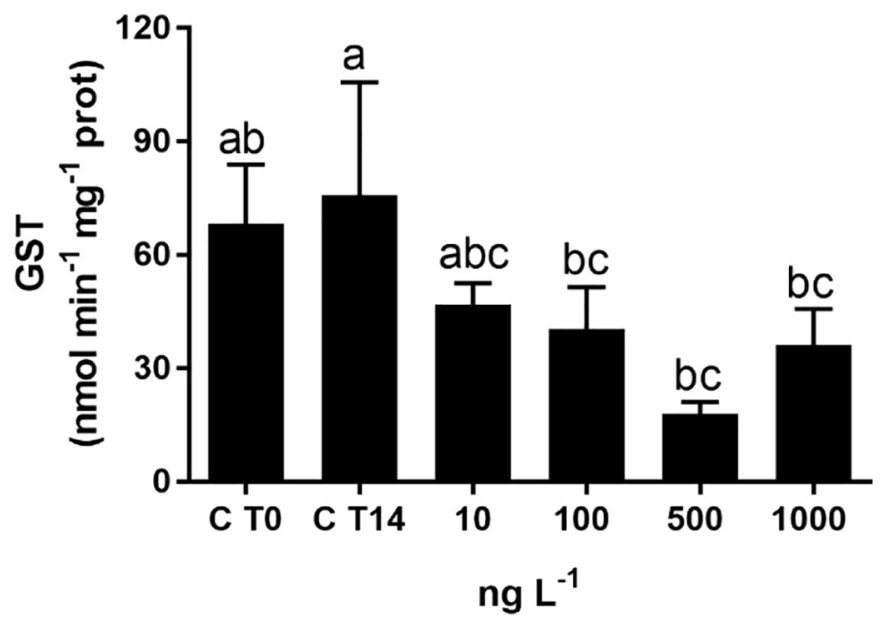

Fig. 5. Biotransformation enzyme activity (mean \pm S.D.) in $N$. diversicolor of control conditions (CT0 and CT14) and exposed to CP $\left(10,100,500\right.$ and $\left.1000 \mathrm{ng} \mathrm{L}^{-1}\right)$ for 14 days. Different letters indicate significant differences among treatments (KruskalWallis, $p<0.05$ ). the plot score indicated a clear separation between organisms from control conditions and contaminated treatments, in which CT0 and CT14 organisms are close-related in both axis projections. The first axis mainly explains the decline in SOD, T-GPx, GST, in addition to the induction of oxidative and significant DNA damage as detrimental effects of suppression of the lines of defense, in animals exposed to the two highest CP levels.

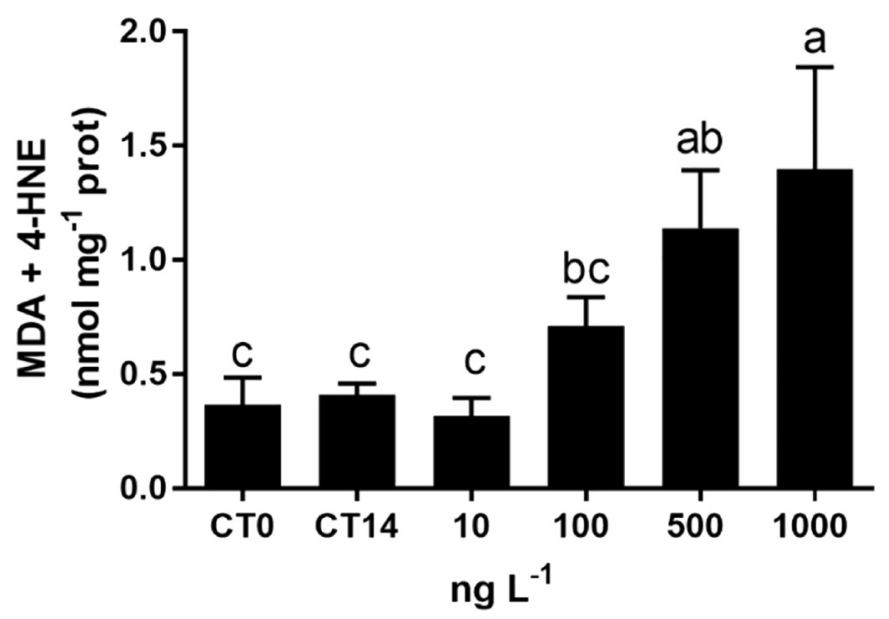

Fig. 6. LPO activity (mean \pm standard deviation) (MDA +4 -HNE nmol $\cdot \mathrm{mg}^{-1}$ protein) in animals of control conditions (CT0 and CT14) and exposed to CP at 10, 100, 500 and $1000 \mathrm{ng} \mathrm{L}^{-1}$ for 14 days. Different letters indicate significant differences among treatments (ANOVA, $p<0.05$ ). 
Table 2

Genotoxic effects in polychaetes N. diversicolor unexposed and after 14 days of exposure to CP. DNA damage (average \pm SEM) is expressed as tail DNA \%. Frequency of coelomocytes distributed by grade of DNA damage (\%). Different letters represent statistical differences between treatments, during the exposure period. Percentage of coelomocytes distributed through damage criteria (i.e. minimal to extreme).

\begin{tabular}{|c|c|c|c|c|c|c|}
\hline \multirow[t]{2}{*}{ Treatment } & \multirow[t]{2}{*}{ DNA tail (\%) } & \multicolumn{5}{|c|}{ DNA damage grade (\%) } \\
\hline & & Minimal & Low & Mid & High & Extreme \\
\hline Control & $7.5^{\mathrm{a}}( \pm 0.4)$ & 69.2 & 30.8 & 0 & 0 & 0 \\
\hline $10 \mathrm{ng} \mathrm{CP} \mathrm{L}{ }^{-1}$ & $10.26^{\mathrm{b}}( \pm 0.57)$ & 59 & 30.1 & 10.9 & 0 & 0 \\
\hline $100 \mathrm{ng} \mathrm{CP} \mathrm{L}{ }^{-1}$ & $10.59^{\mathrm{b}}( \pm 0.36)$ & 51.5 & 46.2 & 2.3 & 0 & 0 \\
\hline $500 \mathrm{ng} \mathrm{CP} \mathrm{L}{ }^{-1}$ & $9.97^{\mathrm{b}}( \pm 0.42)$ & 57.2 & 40.0 & 2.8 & 0 & 0 \\
\hline 1000 ng CP L ${ }^{-1}$ & $11.83^{\mathrm{b}}( \pm 0.55)$ & 50.8 & 41.2 & 8.0 & 0 & 0 \\
\hline
\end{tabular}

In the second component it is highlighted the divergence of biomarkers profile between control groups and the lowest CP concentration (i.e. $10 \mathrm{ng} \mathrm{L}^{-1}$ ). The non-monotonic behavior of burrowing in such exposed group elicited a reduced number of animals excavating. Likewise, at the lower CP level, SOD, CAT and GPX-Se are triggered, although no significant differences were detected $(p>0.05)$.

\section{Discussion}

$\mathrm{CP}$ is a widely used chemotherapy agent applied worldwide, with diffuse release in aquatic systems through hospital and domestic wastewater discharges. Despite that its partition is preferential through the water phase, geochemical and hydrodynamic data indicate that $\mathrm{CP}$ may settle in the sediments (Xie, 2012; Kosjek and Heath, 2011). Coastal polychaetes have been increasingly applied as bioindicators in ecotoxicological assessments evaluating biochemical alterations caused by pharmaceuticals (Maranho et al., 2014; Pires et al., 2016a, Fonseca et al., 2017). The species Nereis diversicolor indicates, as addressed in previous studies, high sensitivity to low levels ( $\mathrm{ng} \mathrm{L}^{-1}$ and g $^{-1}$ ) of pharmaceuticals containing different physicochemical properties and MoA, translated by disturbances in behavior, energy status, oxidative stress, neurotoxicity, oxidative damage, and genotoxicity (Maranho et al., 2014, 2015; Pires et al., 2016a; Fonseca et al., 2017).
In the present study, burrowing activity seemed to be nonmonotonically over $\mathrm{CP}$ levels, in which animals were most impaired at lower concentrations, whereas at the highest concentrations (i.e. $1000 \mathrm{ng} \mathrm{L}^{-1}$ ) all animals were fully buried after $30 \mathrm{~min}$ (Fig. 2). As stated by Doyotte et al. (1997), it is not a general rule that an increase in contaminant concentrations induces the expected harmful effect, as proposed by the dose-response curve. Lagarde et al. (2015) reviewed different profiles of non-monotonic dose responses for various physiological and behavioural effects, in several organs or systems. Accordingly, the present burrowing profile corroborated with a bell-shaped dose-effect relationship in which minimal effects are induced at the two extreme doses (control and $1000 \mathrm{ng} \mathrm{L}^{-1}$ ), although the mechanisms involved in the burrowing at the highest $\mathrm{CP}$ concentration may not be similar to the observed in controls. Hence, at very high doses, unspecific effects will, for instance, occur because the organism would be completely overwhelmed by the substance, through non-specific biological mechanisms (Lagarde et al., 2015). Many components of signaling pathways and their cross-talk could contribute to understand the non-linearity and dynamical monotonicity in response to stimuli (Van Wijk et al., 2015).

Contrarily to the present results, animals remained emerged at the highest concentration of the cytotoxic drug cisplatin $\left(100 \mathrm{ng} \mathrm{Pt} \mathrm{L}^{-1}\right)$, together with neurotoxic effects associated to AChE inhibition (Fonseca et al., 2017). CP has been widely reported to inhibit brain and retinal AChE activity in different biological models (Al-Jafari, 1993; Al-Jafari et al., 1995; Kamal et al., 2010) with hydrophobic interactions providing $\mathrm{CP}$ positioning within the acyl pockets and catalytic site of the enzyme (Shakil et al., 2011). However, herein, no effects of neurotoxicity were observed (Fig. 3), as a potential result of docking between the enzyme and $\mathrm{CP}$ that may not be well accomplished in the present biological model (Valasani et al., 2013). Besides, CP levels applied herein are too low to observe neurotoxic effects, compared to concentration range (mg-g L ${ }^{-1}$ ) used in experiments with vertebrates (Santos and Pacheco, 1995).

In general, cancer cells are characterized by increased aerobic glycolysis, followed by high levels of reactive oxygen species (ROS), which need to be counteracted by expression of ROS-scavenging systems for the success of the first stage of tumor formation (Gorrini et al., 2013).

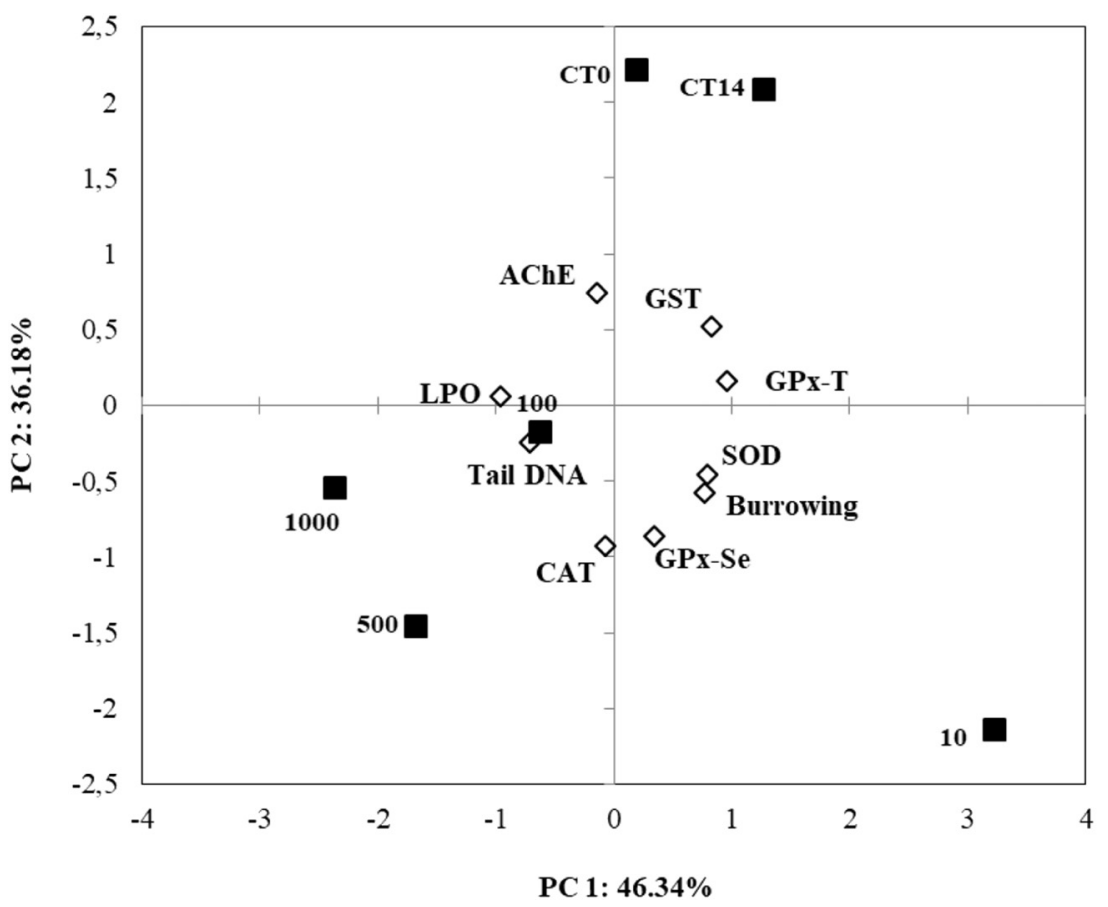

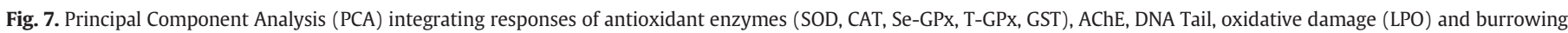
behavior of $N$. diversicolor, exposed to control conditions (CT0: day 0; CT14: day 14) and to different CP concentrations (10, 100,500 and 1000 ng $\mathrm{L}^{-1}$ ). 
The administration of anticancer drugs relies on the enhancement of ROS levels to trigger cancer cells death through signaling pathways and cellular damage (Conklin, 2004; Gorrini et al., 2013). CP produces additional oxidative stress through the acrolein metabolite (Arumugam et al., 1999; Dumontet et al., 2001; Oboh and Ogunruku, 2010). In this sense, its cytotoxic MoA combined with the suppression of cellular defenses are effective to impair normal growing cells, including marine non-target species (Fonseca et al., 2017).

In the present study, although significant differences were not statistically detected in SOD activity when compared to controls $(p>0.05)$, data showed a slight induction of SOD activity at the two lowest concentrations (Fig. 4A), triggered as a potential consequence of polychaetes adaptation to overcome the stress from the drug (Sun and Zhou, 2008). At the two highest levels of CP, SOD activity was inhibited (Fig. 4A), as observed at 14-day of exposure to the anticancer drug CisPt, at $100 \mathrm{ng} \mathrm{Pt} \mathrm{L}{ }^{-1}$ (Fonseca et al., 2017). In rats, the inhibition of SOD activity was also observed in animals treated with intraperitoneal injection, either with 5 or $100 \mathrm{mg} \mathrm{CP} \mathrm{kg}^{-1}$ (Patel and Block, 1985). Conversely, in the marine mussel Mytilus galloprovincialis, over the 2-week exposure to CisPt (100 ng Pt L ${ }^{-1}$ ), a higher induction and detoxification of SOD activity was observed in the digestive gland compared to the gills, denoting the primary role of the former in recovery processes in this species (Trombini et al., 2016; Faria et al., 2009). Giving the predominant role of SOD as the first line of defense in ROS scavenging, by converting the highly reactive superoxide anion $\left(\mathrm{O}_{2}^{-}\right)$into hydrogen peroxide $\left(\mathrm{H}_{2} \mathrm{O}_{2}\right)$, its depletion yields cell redox unbalance by $\mathrm{O}_{2}^{-}$accumulation, thus elevating the oxidizing potential (Ben Ameur et al., 2012; Cozzari et al., 2015; Djordjevic et al., 2011).

Regarding the second line of defense against ROS, CAT activity acts as a catalyst of the SOD activity by-product $\mathrm{H}_{2} \mathrm{O}_{2}$ for its detoxification into water (Faria et al., 2009; Gonzalez-Rey and Bebianno, 2012). Even though it is expected a coping behavior among enzymes in the metabolic pathway, CAT activity responses depicted a non-monotonic profile over CP levels (Fig. 4B), might be attributed to other ROS detoxifying process, as stated by Aguirre-Martínez et al. (2013) and Gonzalez-Rey and Bebianno (2012). In the case of CP metabolism, the CYP450 activation for PAM and acrolein detoxification combined with the uncoupled catalytic cycle may be accountable to form extra amounts of oxyradicals that need to be neutralized (Dumontet et al., 2001; Harskamp et al., 2012; Oboh and Ogunruku, 2010). The burst of superoxide induced bt CP that cannot be efficiently eliminated through SOD activity is promptly buffered by the GSH (Aquilano et al., 2014). The electrophilic acrolein produces cellular damage after binding to GSH and reduces their availability inside the cells, hence impairing the antioxidant glutathione dependent-system and also increasing free radical generation (Peña-Llopis et al., 2002; Singh et al., 2014).

The activity of Se-GPx is an important alternative to counteract harmful electrophiles produced during oxidative damage (Djordjevic et al., 2011) and is a key enzyme that detoxifies $\mathrm{H}_{2} \mathrm{O}_{2}$ and converts lipid hydroperoxydes to non-toxic alcohols (Charushila and Subodhini, 2015). The present results demonstrate that Se-GPx was unaffected at any of the CP levels to which worms were exposed to (Fig. 4C). In contrast, $N$. diversicolor exhibited a clear induction of that enzyme when specimens were exposed to CisPt, as an offset of CAT activity decrease (Fonseca et al., 2017), once both enzymes are associated to enzymatic hydrogen peroxide scavenging (Cozzari et al., 2015). As in the present study CAT activity was not inhibited. It may be hypothesized that the activation of Se-GPx was not particularly relevant to counteract severe oxidative challenge. Notwithstanding, T-GPx is also recognized as the most important enzymatic reductor agent of lipid peroxides and emerges as a compensatory response in cases where SOD activity is inhibited (Aquilano et al., 2014). In contrast, the excess of nonneutralized oxyradicals, such as superoxide, may lead to exhaustion or inhibition of the defense system culminating in T-GPx inactivation, as observed in worms exposed to 500 and $1000 \mathrm{ng} \mathrm{L}^{-1}$ (Fig. 4D). Thus, once T-GPX activity decreased, more hydrogen peroxide is accumulated in the cell to the point of causing oxidative damage and activation of inflammatory pathways (Yu et al., 2006). T-GPx activity inhibition also occurred in the digestive gland of the clam Ruditapes philippinarum exposed to the antiepileptic carbamazepine and the antibiotic novobiocin, as a reflection of pro-oxidant forces overcoming antioxidant defenses (Aguirre-Martínez et al., 2016).

GST is involved in the Phase II biotransformation metabolism by catalyzing the nucleophilic attack of GSH onto highly electrophilic compounds, thus denoting an important role in homeostasis as well as in detoxification and clearance of the drugs (Aguirre-Martínez et al., 2013; Faria et al., 2009; Hayes et al., 2005). Such enzyme can reduce lipid hydroperoxides together with GPx, and is related to protection against apoptosis (Prabhu et al., 2004). Several studies have pointed out its induction in aquatic invertebrates after pharmaceuticals exposure as an outcome of its activation and antioxidant role (Martin-Diaz et al., 2009; Buffet et al., 2014; Aguirre-Martínez et al., 2013; Maranho et al., 2014; Aguirre-Martínez et al., 2016; Pires et al., 2016 a,b). The mismatch between our results and those reported may be related to different patterns of response associated to the drug's MoA and disparities across species regarding their defensive systems to metabolize xenobiotics (Cozzari et al., 2015; Faria et al., 2009; Sun and Zhou, 2008). No CP immunotoxicity was observed in the aquatic gastropod Lymnaea stagnalis even at therapeutic exposure levels, which was suggested to be related to the lack of appropriate converting enzymes of the prodrug (Boisseaux et al., 2017). Contrarily, polychaetes N. diversicolor exhibited a sharp decline in the biotransformation system in a 14-day bioassay conducted with the electrophilic CisPt, which resembles the highly electrophilic binding to the drug (Fonseca et al., 2017). Nevertheless, Gonzalez-Rey and Bebianno (2012) observed a significant decrease of GST activity in mussels Mytilus galloprovincialis exposed to ibuprofen (250 $\mathrm{ng} \mathrm{L}^{-1}$ ), corroborating the data regarding the polychaete Diopatra neapolitana, in systems containing carbamazepine $\left(3 \mu \mathrm{g} \mathrm{L}^{-1}\right)$ (Pires et al., 2016b).

Lipid peroxidation is initiated by the attack on fatty acids of biomolecules that possess sufficient reactivity to abstract a hydrogen atom from methylene carbon in the side chain (Halliwell and Chirico, 1993). Cellular lipids are the primary targets of generated ROS and subsequently LPO occurs, as in human cells exposed to hydroxylcyclophosphamide (Dumontet et al., 2001). Morphological changes were observed in type II-alveolar rats epithelial cells as a result of oxidative stress (e.g. decrease in SOD and glutathione reductase activities) and an enhancement of LPO occurs after 7 days of exposure to $150 \mathrm{mg} \mathrm{CP} \mathrm{kg}{ }^{-1}$ body weight (Sulkowska et al., 1998). LPO is one of the main toxic effects caused by $\mathrm{CP}$ and responsible for several side effects during chemotherapy (Sulkowska et al., 1998), due to the production of the reactive aldehyde acrolein formed by $\beta$-elimination of aldophosphamide. Besides an important component produced by $\mathrm{CP}$ for cytotoxicity in cancer cells, this metabolite is also known as an overall secondary reactive species-product of LPO that triggers further chain reaction (Dumontet et al., 2001; Conklin, 2004; Singh et al., 2014). The increased levels of LPO by-products at the higher CP levels (500 and $1000 \mathrm{ng} \mathrm{L}^{-1}$ ) (Fig. 6) may be a result of an inefficient biochemical antioxidant defense system (Gonzalez-Rey and Bebianno, 2012; Freitas et al., 2016; Pires et al., 2016a; Fonseca et al., 2017), depicted by the depletion of SOD, T-GPx and GST activities, as indicated in the first axis of the PCA (Fig. 7). Besides enzymes activity suppression, chemotherapy treatment produce additional ROS generation (Conklin, 2004), which may lead to DNA damage, mutations and apoptosis to normal growing cells, such as observed in marine non-target species exposed to cisplatin and methotrexate (Fonseca et al., 2017; Moreira et al., 2016).

$\mathrm{CP}$ has bifunctional and $\mathrm{S}_{\mathrm{N}} 1$ molecular properties, with two reactive moieties towards bases of opposite DNA double strands (Anderson et al., 1995). The major alkylating agent following CP metabolism is PAM, which undergoes spontaneous hydrolysis to form reactive aziridium intermediate species, that binds to nucleophilic N7-position of guanine in DNA. Alkylation to oxygen atoms of DNA, especially at 
the 06-position of guanine, are also generated at lower frequency than $\mathrm{N}$-alkyl adducts, however its biological relevance is even greater considering the readily mispair of bases during DNA replication (Fu et al., 2012). The array of lesions caused by CP alkylation impair genome integrity by inducing mutagenesis, besides DNA replication and eventual responsive signaling for cell death if DNA repair mechanisms are not efficient (Deans and West, 2011; Fu et al., 2012). DNA damage caused by CP is widely described in vertebrates cells, in which administration by therapeutically treated-patients and rats exposed to this drug showed gene mutations, sister chromatid exchange, DNA adducts, DNA-DNA and DNA-protein crosslinks in somatic cells, especially by the ultimate crosslinking metabolite PAM (Crook et al., 1986; Codrington et al., 2004). Few studies were so far conducted to access genotoxicity responses to anticancer drugs considering in vivo uptake by marine organisms (Fonseca et al., 2017; Parrella et al., 2015). In the present study, results showed a significant increase in DNA damage in CP-treated animals compared to controls (Table 2). Animals exposed to CP, particularly to $1000 \mathrm{ng} \mathrm{L}^{-1}$, had a significantly higher density of DNA in the tail compared to controls (CT14) $(p<0.05)$. The grade of DNA damage was similar among CP treatments, although the lowest and highest concentrations indicated more burden of mid damage.

DNA damage caused by anticancer drugs were addressed in other aquatic biological models, at levels ranging from low $n \mathrm{~L}^{-1}$ to $\mu \mathrm{g} \mathrm{L}^{-1}$ : the bivalve mollusc Mytilus galloprovincialis, exposed to cisplatin (Trombini et al., 2016); the microcrustaceans Ceriodaphnia dubia and Daphnia magna, exposed to 5-FU, capecitabine, cisplatin, doxorubicin, etoposide and imatinib (Parrella et al., 2014a, 2014b, 2015); and ZFL cell lines of the fish Danio rerio to the tyrosine kinase inhibitor imatinib (Novak et al., 2016). However, the 14-day exposure of $N$. diversicolor to the alkylating agent cisplatin (Fonseca et al., 2017) yielded no genotoxicity effect at a similar range of concentrations. Cytotoxic metabolites of $\mathrm{CP}$ are transported and diffused into cells interacting with DNA sites after prodrug enzymatic activation, certified with the increasing DNA damage over increasing CP levels, however, this needs to be confirmed with $\mathrm{CP}$ levels accumulated in the worms.

\section{Conclusions}

The present study highlights the cytotoxic effects of the antineoplasic drug CP on normal proliferative cells of polychaetes, by binding to DNA and interfering in antioxidant status. Chronic exposure of polychaetes $N$. diversicolor to CP levels of 500 and $1000 \mathrm{ng} \mathrm{L}^{-1}$ in seawater led to an inhibition of the antioxidant enzymes activity, stimulating LPO by-products and DNA damage. The analysed biomarkers suggest that the prodrug $\mathrm{CP}$ is probably metabolically activated by $N$. diversicolor into PAM and acrolein, respectively responsible for the antineoplastic properties and toxic effects observed, nonetheless, this needs to be confirmed.

\section{Acknowledgements}

This work was financed and supported by the Brazilian National Council for Scientific and Technological Development (CNPq), through the Science Without Borders Program (202360/2014-8). This work was also supported by the Portuguese Science Foundation (FCT) through the grant UID/MAR/00350/2013 attributed to CIMA, University of Algarve.

\section{References}

Abessa, D.M.S., Carr, R.S., Rachid, B.R.F., Sousa, E.C.P.M., Hortelani, M.A., Sarkis, J.E., 2005. Influence of a Brazilian sewage outfall on the toxicity and contamination of adjacent sediments. Mar. Pollut. Bull. 50, 875-885.

Aguirre-Martínez, G.V., Del Valls, T.A., Martín-Díaz, M.L., 2013. Identification of biomarkers responsive to chronic exposure to pharmaceuticals in target tissues of Carcinus maenas. Mar. Environ. Res. 87-88:1-11. https://doi.org/10.1016/j. marenvres.2013.02.011.
Aguirre-Martínez, G.V., DelValls, T.A., Martín-Díaz, M.L., 2016. General stress, detoxification pathways, neurotoxicity and genotoxicity evaluated in Ruditapes philippinarum exposed to human pharmaceuticals. Ecotoxicol. Environ. Saf. 124:18-31. https://doi. org/10.1016/j.ecoenv.2015.09.031.

Al-Jafari, A.A., 1993. The toxicological effect of cyclophosphamide on acetylcholinesterase activity. Toxicol. Lett. 66:125-131. https://doi.org/10.1016/0378-4274(93)90087-E.

Al-Jafari, A.A., Duhaiman, A.S., Kamal, M.A., 1995. Inhibition of human acetylcholinesterase by cyclophosphamide. Toxicology 96:1-6. https://doi.org/10.1016/0300-483X (94)02848-0.

Anderson, D., Bishop, J.B., Garner, R.C., Ostrosky-wegman, P., Selby, P.B., 1995. Cyclophosphamide: review of its mutagenicity for an assessment of potential germ cell risks. Mutat. Res. 330, 115-181.

Aquilano, K., Baldelli, S., Ciriolo, M.R., 2014. Glutathione: new roles in redox signalling for an old antioxidant. Front. Pharmacol.:1-12 https://doi.org/10.3389/fphar.2014.00196 5 AUG.

Araujo, G.S., Moreira, L.B., Morais, R.D., Davanso, M.B., Garcia, T.F., Cruz, A.C.F., Abessa, D.M.S., 2013. Ecotoxicological assessment of sediments from an urban marine protected area (Xixova-Japui State Park, SP, Brazil). Mar. Pollut. Bull. 75:62-68. https://doi.org/10.1016/j.marpolbul.2013.08.005.

Arumugam, N., Thanislass, J., Ragunath, K., Devaraj, S.N., Devaraj, H., 1999. Acroleininduced toxicity - defective mitochondrial function as a possible mechanism. Arch. Environ. Contam. Toxicol. 36, 373-376.

ASTM, 2009. Standard Guide for Conducting Sediment Toxicity Tests With Polychaetous Annelids (E 1611-00).

Azuma, T., Arima, N., Tsukada, A., Hirami, S., Matsuoka, R., Moriwake, R., Ishiuchi, H., Inoyama, T., Teranishi, Y., Yamaoka, M., Ishida, M., Hisamatsu, K., Yunoki, A., Mino, Y., 2017. Distribution of six anticancer drugs and a variety of other pharmaceuticals, and their sorption onto sediments, in an urban Japanese river. Environ. Sci. Pollut. Res. 24:19021-19030. https://doi.org/10.1007/s11356-017-9525-0.

Bagley, C.M., Bostick, F.W., Devita, V.T., 1973. Clinical pharmacology of cyclophosphamide. Cancer Res. 33, 226-233.

Balbinder, E., Reich, C.I., Shugarts, D., Keogh, J., Fibiger, R., Jones, T., Banks, A., 1981. Relative mutagenicity of some urinary metabolites of the antitumor drug cyclophosphamide. Cancer Res. 41, 2967-2972.

Ben Ameur, W., de Lapuente, J., El Megdiche, Y., Barhoumi, B., Trabelsi, S., Camps, L., Serret J., Ramos-López, D., Gonzalez-Linares, J., Driss, M.R., Borràs, M., 2012. Oxidative stress, genotoxicity and histopathology biomarker responses in mullet (Mugil cephalus) and sea bass (Dicentrarchus labrax) liver from Bizerte Lagoon (Tunisia). Mar. Pollut. Bull. 64:241-251. https://doi.org/10.1016/j.marpolbul.2011.11.026.

Benedict, W.F., Baker, M.S., Haroun, L., Choi, E., Ames, B.N., 1977. Mutagenicity of cancer chemotherapeutic agents in the Salmonella/microsome test. Cancer Res. 37, 209-2213.

Boisseaux, P., Noury, P., Thomas, H., Garric, J., 2017. Immune responses in the aquatic gastropod Lymnaea stagnalis under short-term exposure to pharmaceuticals of concern for immune systems: diclofenac, cyclophosphamide and cyclosporine A. Ecotoxicol Environ. Saf. 139:358-366. https://doi.org/10.1016/j.ecoenv.2017.02.003.

Bonnard, M., Romeo, M., Amiard-Triquet, C., 2009. Effects of copper on the burrowing behavior of estuarine and coastal invertebrates, the polychaete Nereis diversicolor and the bivalve Scrobicularia plana. Hum. Ecol. Risk. Assess. 15:11-26. https://doi.org/ $10.1080 / 10807030802614934$.

Bonnet, J.-L., Dusser, M., Bohatier, J., Laffosse, J., 2003. Cytotoxicity assessment of three therapeutic agents, cyclosporin-A, cisplatin and doxorubicin, with the ciliated protozoan Tetrahymena pyriformis. Res. Microbiol. 154:375-385. https://doi.org/10.1016/ S0923-2508(03)00085-8.

Booker, V., Halsall, C., Llewellyn, N., Johnson, A., Williams, R., 2014. Prioritising anticancer drugs for environmental monitoring and risk assessment purposes. Sci. Total Environ. 474, 159-170.

Borgatta, M., Decosterd, L., Waridel, P., Buclin, T., Chèvre, N., 2015. The anticancer drug metabolites endoxifen and 4-hydroxy-tamoxifen induce toxic effects on Daphnia pulex in a two-generation study. Sci. Total Environ. 520, 232-240.

Borgatta, M., Waridel, P., Decosterd, L.A., Buclin, T., Chèvre, N., 2016. Multigenerational ef fects of the anticancer drug tamoxifen and its metabolite 4-hydroxy-tamoxifen on Daphnia pulex. Sci. Total Environ. 545-546:21-29. https://doi.org/10.1016/j. scitotenv.2015.11.155.

Bradford, M.M., 1976. A rapid and sensitive method for the quantitation of microgram quantities of protein utilizing the principle of protein-dye binding. Anal. Biochem. $72,248-254$.

Brezovsek, P., Elersek, T., Filipic, M., 2014. Toxicities of four anti-neoplastic drugs and their binary mixtures tested on the green alga Pseudokirchneriella subcapitata and the cyanobacterium Synechococcus leopoliensis. Water Res. 52, 168-177.

Buerge, I.J., Buser, H.R., Poiger, T., Müller, M.D., 2006. Occurrence and fate of the cytostatic drugs cyclophosphamide and ifosfamide in wastewater and surface waters. Environ. Sci. Technol. 40:7242-7250. https://doi.org/10.1021/es0609405.

Buffet, P.-E., Poirier, L., Zalouk-Vergnoux, A., Lopes, C., Amiard, J.-C., Gaudin, P., Risso-de Faverney, C., Guibbolini, M., Gilliland, D., Perrein-Ettajani, H., Valsami-Jones, E., Mouneyrac, C., 2014. Biochemical and behavioural responses of the marine polychaete Hediste diversicolor to cadmium sulfide quantum dots (CdS QDs): waterborne and dietary exposure. Chemosphere 100:63-70. https://doi.org/10.1016/j. chemosphere.2013.12.069.

Buruaem, L.M., Hortellani, M.A., Sarkis, J.E., Costa-Lotufo, L.V., Abessa, D.M.S., 2012. Contamination of port zone sediments by metals from Large Marine Ecosystems of Brazil. Mar. Pollut. Bull. 64:479-488. https://doi.org/10.1016/j.marpolbul.2012.01.017.

Busetti, F., Linge, K.L., Heitz, A., 2009. Analysis of pharmaceuticals in indirect potable reuse systems using solid-phase extraction and liquid chromatography-tandem mass spectrometry. J. Chromatogr. A 1216:5807-5818. https://doi.org/10.1016/j. chroma.2009.06.001. 
Calamari, D., Zuccato, E., Castiglioni, S., Bagnati, R., Fanelli, R., 2003. Strategic survey of therapeutic drugs in the rivers Po and Lambro in northern Italy. Environ. Sci. Technol. 37, 1241-1248.

Castiglioni, S., Bagnati, R., Calamari, D., Fanelli, R., Zuccato, E., 2005. A multiresidue analytical method using solid-phase extraction and high-pressure liquid chromatography tandem mass spectrometry to measure pharmaceuticals of different therapeutic classes in urban wastewaters. J. Chromatogr. A 1092:206-215. https://doi.org/10.1016/j. chroma.2005.07.012.

Česen, M., Kosjek, T., Laimou-Geraniou, M., Kompare, B., Širok, B., Lambropolou, D., Heath, E., 2015. Occurrence of cyclophosphamide and ifosfamide in aqueous environment and their removal by biological and abiotic wastewater treatment processes. Sci. Total Environ. 527-528:465-473. https://doi.org/10.1016/j.scitotenv.2015.04.109.

Česen, M., Elersek, T., Novak, M., Zegura, B., Kosjek, T., Filipič, M., Heath, E., 2016. Ecotoxicity and genotoxicity of cyclophospamide, ifosfamide, their metabolites/transformation products and their mixtures. Environ. Pollut. 210, 192-201.

Charushila, K., Subodhini, A., 2015. Evaluation of serum antioxidants during adjuvant chemotherapy of breast cancer - a prospective observational study. Biochem. Anal. Biochem. 4:2-7. https://doi.org/10.4172/2161-1009.1000171.

Codrington, A.M., Hales, B.F., Robaire, B., 2004. Spermiogenic germ cell phase - specific DNA damage following cyclophosphamide exposure. J. Androl. 25:354-362. https:// doi.org/10.1002/j.1939-4640.2004.tb02800.x.

Colovic, M.B., Krstic, D.Z., Lazarevic-Pasti, T.D., Bondzic, A.M., Vasic, V.M., 2013. Acetylcholinesterase inhibitors: pharmacology and toxicology. Curr. Neuropharmacol. 11: 315-335. https://doi.org/10.2174/1570159X11311030006.

Cong, Y., Banta, G.T., Selck, H., Berhanu, D., Valsami-jones, E., Forbes, V.E., 2011. Toxic effects and bioaccumulation of nano-, micron- and ionic-Ag in the polychaete, Nereis diversicolor. Aquat. Toxicol. 105:403-411. https://doi.org/10.1016/j. aquatox.2011.07.014.

Conklin, K.A., 2004. Chemotherapy-associated oxidative stress: impact on chemotherapeutic effectiveness. Integr. Cancer Ther. 3:294-300. https://doi.org/10.1177/ 1534735404270335

Cozzari, M., Elia, A.C., Pacini, N., Smith, B.D., Boyle, D., Rainbow, P.S., Khan, F.R., 2015. Bioaccumulation and oxidative stress responses measured in the estuarine ragworm (Nereis diversicolor) exposed to dissolved, nano- and bulk-sized silver. Environ. Pollut. 198:32-40. https://doi.org/10.1016/j.envpol.2014.12.015.

Crane, M., Watts, C., Boucard, T., 2006. Chronic aquatic environmental risks from exposure to human pharmaceuticals. Sci. Total Environ. 367:23-41. https://doi.org/10.1016/j. scitotenv.2006.04.010

Crook, T.R., Souhami, R.L., McLean, A.E.M., 1986. Cytotoxicity, DNA cross-linking, and single strand breaks induced by activated cyclophosphamide and acrolein in human leukemia cells. Cancer Res. 46, 5029-5034.

Deans, A.J., West, S.C., 2011. DNA interstrand crosslink repair and cancer. Nat. Rev. Cance 11:467-480. https://doi.org/10.1038/nrc3088.

DellaGreca, M., Iesce, M.R., Isidori, M., Nardelli, A., Previtera, L., Rubino, M., 2007. Phototransformation products of tamoxifen by sunlight in water. Toxicity of the drug and its derivatives on aquatic organisms. Chemosphere 67:1933-1939. https://doi.org/10.1016/j.chemosphere.2006.12.001.

Djordjevic, J., Djordjevic, A., Adzic, M., Elakovic, I., Matic, G., Radojcic, M.B., 2011. Fluoxetine affects antioxidant system and promotes apoptotic signaling in Wistar rat liver Eur. J. Pharmacol. 659:61-66. https://doi.org/10.1016/j.ejphar.2011.03.003.

Doyotte, A., Cossu, C., Jacquin, M.C., Babut, M., Vasseur, P., 1997. Antioxidant enzymes, glutathione and lipid peroxidation of experimental or field exposure in the gills and the digestive gland of the freshwater bivalve Unio tumidus. Aquat. Toxicol. 39, 93-110.

Dumontet, C., Drai, J., Thieblemont, C., Hequet, O., Espinouse, D., Bouafia, F., Salles, G., Coiffier, B., 2001. The superoxide dismutase content in erythrocytes predicts shortterm toxicity of high-dose cyclophosphamide. Br. J. Haematol. 112:405-409. https://doi.org/10.1046/j.1365-2141.2001.02595.x.

Ellman, G.L., Courtney, K.D., Andres, V., Featherstone, R.M., 1961. A new and rapid colorimetric determination of acetylcholinesterase activity. Biochem. Pharmacol. 7 : 88-95. https://doi.org/10.1016/0006-2952(61)90145-9.

Emadi, A., Jones, R.J., Brodsky, R.A., 2009. Cyclophosphamide and cancer: golden anniversary. Nat. Rev. Clin. Oncol. 6:638-647. https://doi.org/10.1038/nrclinonc.2009.146.

Erdelmeier, I., Gérard-Monnier, D., Yadan, J.C., Chaudière, J., 1998. Reactions of N-methyl2-phenylindole with malondialdehyde and 4-hydroxyalkenals. Mechanistic aspects of the colorimetric assay of lipid peroxidation. Chem. Res. Toxicol. 11:1184-1194. https://doi.org/10.1021/tx970180z.

Farber, E., 1973. Carcinogenesis - cellular evolution as a unifying thread: presidential address. Cancer Res. 33, 2537-2550.

Faria, M., Carrasco, L., Diez, S., Riva, M., Bayona, J., Barata, C., 2009. Multi-biomarker responses in the freshwater mussel Dreissena polymorpha exposed to polychlorobiphenyls and metals. Comp. Biochem. Physiol. Part C 149:281-288. https://doi.org/10.1016/j.cbpc.2008.07.012.

Ferrando-Climent, L., Rodriguez-Mozaz, S., Barceló, D., 2014. Incidence of anticancer drugs in an aquatic urban system: from hospital effluents through urban wastewater to natural environment. Environ. Pollut. 193:216-223. https://doi.org/10.1016/j. envpol.2014.07.002.

Ferreira, J.G., Simas, T., Nobre, A., Silva, M.C., Shifferegger, K., Lencart-Silva, J., 2003. Identification of sensitive areas and vulnerable zones in transitional and coastal Portuguese systems. Application of the United States National Estuarine Eutrophication Assessment to the Minho, Lima, Douro, Ria de Aveiro, Mondego, Tagus, Sado, Mira, Ina. IMAR 79-94.

Fonseca, T.G., Morais, M.B., Rocha, T., Abessa, D.M.S., Aureliano, M., Bebianno, M.J., 2017. Ecotoxicological assessment of the anticancer drug cisplatin in the polychaete Nereis diversicolor. Sci. Total Environ. 575:162-172. https://doi.org/10.1016/j. scitotenv.2016.09.185
Franquet-Griell, H., Cornadó, D., Caixach, J., Ventura, F., Lacorte, S., 2017. Determination of cytostatic drugs in Besòs River (NE Spain) and comparison with predicted environmental concentrations. Environ. Sci. Pollut. Res. 24:6492-6503. https://doi.org/ 10.1007/s11356-016-8337-y.

Freitas, R., Almeida, Â., Calisto, V., Velez, C., Moreira, A., Schneider, R.J., Esteves, V.I., Wrona, F.J., Figueira, E., Soares, A.M.V.M., 2016. The impacts of pharmaceutical drugs under ocean acidification: new data on single and combined long-term effects of carbamazepine on Scrobicularia plana. Sci. Total Environ. 541:977-985. https://doi.org/ 10.1016/j.scitotenv.2015.09.138.

Fu, D., Calvo, J.A., Samson, L.D., 2012. Balancing Repair and Tolerance of DNA Damage

Geret, F., Serafim, A., Barreira, L., 2002. Response of antioxidant systems to copper in the gills of the clam Ruditapes decussatus. Mar. Environ. Res. 54, 413-417.

Gilard, V., Martino, R., Malet-Martino, M.C., Kutscher, B., Müller, A., Niemeyer, U., Pohl, J., Polymeropoulos, E.E., 1994. Chemical and biological evaluation of hydrolysis products of cyclophosphamide. J. Med. Chem. 37, 3986-3993.

Gomes, T., Araújo, O., Pereira, R., Almeida, A.C., Cravo, A., Bebianno, M.J., 2013. Genotoxicity of copper oxide and silver nanoparticles in the mussel Mytilus galloprovincialis. Mar. Environ. Res. 84:51-59. https://doi.org/10.1016/j. marenvres.2012.11.009.

Gómez-Canela, C., Cortés-Francisco, N., Oliva, X., Pujol, C., Ventura, F., Lacorte, S., Caixach, J., 2012. Occurrence of cyclophosphamide and epirubicin in wastewaters by direct injection analysis-liquid chromatography-high-resolution mass spectrometry. Environ. Sci. Pollut. Res. 19:3210-3218. https://doi.org/10.1007/s11356-012-0826-z.

Gonzalez-Rey, M., Bebianno, M.J., 2012. Non-steroidal anti-inflammatory drug (NSAID) ibuprofen distresses antioxidant defense system in mussel Mytilus galloprovincialis gills. Aquat. Toxicol. 105:264-269. https://doi.org/10.1016/j. aquatox.2011.06.015.

Gorrini, C., Harris, I.S., Mak, T.W., 2013. Modulation of oxidative stress as an anticancer strategy. Nat. Rev. Drug Discov. 12:931-947. https://doi.org/10.1038/nrd4002.

Greenwald, R.A., 1985. Handbook of Methods for Oxygen Radical Research. CRC Press, Boca Raton, FL, USA.

Gross, M.G., 1971. Carbon determination. In: Carver, R.E. (Ed.), Procedures in Sedimentary Petrology. Wiley-Interscience, New York, pp. 573-596.

Habig, W.H., Pabst, M.J., Jakoby, W.B., 1974. Glutathione S-transferase: the first enzymatic step in mercapturic acid formation. J. Biol. Chem. 249, 7130-7139.

Halliwell, B., Chirico, S., 1993. Lipid peroxidation: its mechanism, measurement, and significance. Am. J. Clin. Nutr. 57, 715S-725S.

Harris, C.C., 1976. The carcinogenicity of anticancer drugs: a hazard in man. Cancer 37, 1014-1023.

Harskamp, J., Britz-Mckibbin, P., Wilson, J.Y., 2012. Functional screening of cytochrome P450 activity and uncoupling by capillary electrophoresis. Anal. Chem. 84:862-866. https://doi.org/10.1021/ac202787n.

Hayes, J.D., Flanagan, J.U., Jowsey, I.R., 2005. Glutathione transferases. Annu. Rev. Pharmacol. Toxicol. 45:51-88. https://doi.org/10.1146/annurev. pharmtox.45.120403.095857.

Johnson, A.C., Jürgens, M.D., Williams, R.J., Kümmerer, K., Kortenkamp, A., Sumpter, J.P., 2008. Do cytotoxic chemotherapy drugs discharged into rivers pose a risk to the environment and human health? An overview and UK case study. J. Hydrol. 348: 167-175. https://doi.org/10.1016/j.jhydrol.2007.09.054.

Kamal, M.A., Reale, M., Al-Jafari, A.A., 2010. Multiple approaches to analyse the data for rat brain acetylcholinesterase inhibition by cyclophosphamide. Neurochem. Res. 35: 1501-1509. https://doi.org/10.1007/s11064-010-0199-y.

Kiffmeyer, T., Gotze, H.-J., Jursch, M., Luders, U., 1998. Trace enrichment, chromatographic separation and biodegradation of cytostatic compounds in surface water. J. Anal. Chem. 361, 185-191.

Kosjek, T., Heath, E., 2011. Occurrence, fate and determination of cytostatic pharmaceuticals in the environment. TrAC Trends Anal. Chem. 30:1065-1087. https://doi.org/ 10.1016/j.trac.2011.04.007.

Kovacs, R., Csenki, Z., Bakos, K., Urbányi, B., Horváth, Á., Garaj-Vrhovac, V., Gajski, G., Geric, M., Negreira, N., Alda, M., Barceló, D., Heath, E., Kosjek, T., Zegura, B., Novak, M., Zajc, I., Baebles, S., Rotter, A., Ramsak, Z., Filipic, M., 2015. Assessment of toxicity and genotoxicity of low doses of 5-fluorouracil in zebrafish (Danio rerio) twogeneration study. Water Res. 77, 201-212.

Kovalova, L., Siegrist, H., Singer, H., Wittmer, A., McArdell, C.S., 2012. Hospital wastewater treatment by membrane bioreactor: performance and efficiency for organic micropollutant elimination. Environ. Sci. Technol. 46:1536-1545. https://doi.org/ 10.1021/es203495d

Kwon, J.-W., Armbrust, K.L., 2008. Aqueous solubility, n-octanol-water partition coefficient, and sorption of five selective serotonin reuptake inhibitors to sediments and soils. Bull. Environ. Contam. Toxicol. 81:128-135. https://doi.org/10.1007/s00128008-9401-1.

Lagarde, F., Beausoleil, C., Belcher, S.M., Belzunces, L.P., Emond, C., Guerbet, M., Rousselle, C., 2015. Non-monotonic dose-response relationships and endocrine disruptors: a qualitative method of assessment. Environ. Health 14, 1-15.

Lawrence, R.A., Burk, R.F., 1976. Glutathione peroxidase activity in selenium-deficient rat liver. Biochem. Biophys. Res. Commun. 71, 952-958.

Llewellyn, N., Lloyd, P., Jürgens, M.D., Johnson, A.C., 2011. Determination of cyclophosphamide and ifosfamide in sewage effluent by stable isotope-dilution liquid chromatography - tandem mass spectrometry. J. Chromatogr. A 1218:8519-8528. https://doi. org/10.1016/j.chroma.2011.09.061.

Maranho, L.A., Baena-nogueras, R.M., Lara-martín, P.A., Delvalls, T.A., 2014. Bioavailability, oxidative stress, neurotoxicity and genotoxicity of pharmaceuticals bound to marine sediments. The use of the polychaete Hediste diversicolor as bioindicator species. 134, 353-365.

Maranho, L.A., André, C., DelValls, T.A., Gagné, F., Martín-Díaz, M.L., 2015. Toxicological evaluation of sediment samples spiked with human pharmaceutical products: energy 
status and neuroendocrine effects in marine polychaetes Hediste diversicolor. Ecotoxicol. Environ. Saf. 118:27-36. https://doi.org/10.1016/j.ecoenv.2015.04.010.

Martín, J., Camacho-Muñoz, D., Santos, J.L., Aparicio, I., Alonso, E., 2011. Simultaneous determination of a selected group of cytostatic drugs in water using high-performance liquid chromatography-triple-quadrupole mass spectrometry. J. Sep. Sci. 34: 3166-3177. https://doi.org/10.1002/jssc.201100461.

Martín, J., Camacho-Muñoz, D., Santos, J.L., Aparicio, I., Alonso, E., 2014. Occurrence and ecotoxicological risk assessment of 14 cytostatic drugs in wastewater. Water Air Soil Pollut. 225 (1896):1-10. https://doi.org/10.1007/s11270-014-1896-y.

Martin-Diaz, L., Franzellitti, S., Buratti, S., Valbonesi, P., Capuzzo, A., Fabbri, E., 2009. Effects of environmental concentrations of the antiepilectic drug carbamazepine on biomarkers and cAMP-mediated cell signaling in the mussel Mytilus galloprovincialis. Aquat. Toxicol. 94:177-185. https://doi.org/10.1016/j.aquatox.2009.06.015.

Mater, N., Geret, F., Castillo, L., Faucet-marquis, V., Albasi, C., Pfohl-leszkowicz, A., 2014. In vitro tests aiding ecological risk assessment of ciprofloxacin, tamoxifen and cyclophosphamide in range of concentrations released in hospital wastewater and surface water. $63,191-200$.

Matsumoto, F.E., Cólus, I.M.S., 2000. Micronucleus frequencies in Astyanax bimaculatus (Characidae) treated with cyclophosphamide or vinblastine sulfate. Genet. Mol. Biol. 23:489-492. https://doi.org/10.1590/S1415-47572000000200041.

McCord, J.M., Fridovich, I., 1969. Superoxide disutase: an enzymic function for erythrocuprein (hemocuprein). J. Biol. Chem. 244

Mohn, G.R., Ellenberger, J., 1976. Genetic effects of cyclophosphamide, ifosfamide and trofosfamide. Mutat. Res. 32, 331-360.

Moldovan, Z., 2006. Occurrences of pharmaceutical and personal care products as micropollutants in rivers from Romania. Chemosphere 64:1808-1817. https://doi. org/10.1016/j.chemosphere.2006.02.003.

Moreira, S.M., Lima, I., Ribeiro, R., Guilhermino, L., 2006. Effects of estuarine sediment contamination on feeding and on key physiological functions of the polychaete Hediste diversicolor: laboratory and in situ assays. Aquat. Toxicol. 78:186-201. https://doi. org/10.1016/j.aquatox.2006.03.001.

Moreira, L.B., Maranho, L.A., Baena-Nogueras, R.M., Lara-Martín, P.A., Martín-Díaz, M.L, 2016. Effects of novobiocin and methotrexate on the benthic amphipod Ampelisca brevicornis exposed to spiked sediments. Mar. Environ. Res. 122:169-177. https:// doi.org/10.1016/j.marenvres.2016.11.003.

Moreno-González, R., Rodriguez-Mozaz, S., Gros, M., Barceló, D., León, V.M., 2015. Seasonal distribution of pharmaceuticals in marine water and sediment from a mediterranean coastal lagoon (SE Spain). Environ. Res. 138, 326-344.

Negreira, N., López, M., Alda, D., Barceló, D., 2014. Cytostatic drugs and metabolites in municipal and hospital wastewaters in Spain: filtration, occurrence, and environmental risk. Sci. Total Environ. 497-498, 68-77.

Novak, M., Žegura, B., Nunić, J., Gajski, G., Gerić, M., Garaj-Vrhovac, V., Filipičc, M., 2016. Assessment of the genotoxicity of the tyrosine kinase inhibitor imatinib mesylate in cultured fish and human cells. Mutat. Res. Toxicol. Environ. Mutagen. 814:14-21. https://doi.org/10.1016/j.mrgentox.2016.12.002.

Oboh, G., Ogunruku, O.O., 2010. Cyclophosphamide-induced oxidative stress in brain: protective effect of hot short pepper (Capsicum frutescens L. var. abbreviatum). Exp. Toxicol. Pathol. 62:227-233. https://doi.org/10.1016/j.etp.2009.03.011.

Ou, X., Lien, E., 1985. Carcinogenicity of some anticancer drugs. J. Clin. Hosp. Pharm. 10, 223-242.

Parrella, A., Kundi, M., Lavorgna, M., Criscuolo, E., Russo, C., Isidori, M., 2014a. Toxicity of exposure to binary mixtures of four anti-neoplastic drugs in Daphnia magna and Ceriodaphnia dubia. Aquat. Toxicol. 157, 41-46.

Parrella, A., Lavorgna, M., Criscuolo, E., Russo, C., Fiumano, V., Isidori, M., 2014b. Acute and chronic toxicity of six anticancer drugs on rotifers and crustaceans. Chemosphere $115,59-66$.

Parrella, A., Lavorgna, M., Criscuolo, E., Russo, C., Isidori, M., 2015. Eco-genotoxicity of six anticancer drugs using comet assay in daphnids. J. Hazard. Mater. 286, 573-580.

Patel, J.M., Block, E.R., 1985. Cyclophosphamide-induced depression of the antioxidant defense mechanisms of the lung. Exp. Lung Res. 8:153-165. https://doi.org/10.3109/ 01902148509057519.

Peña-Llopis, S., Ferrando, M.D., Peña, J.B., 2002. Impaired glutathione redox status is associated with decreased survival in two organophosphate-poisoned marine bivalves. Chemosphere 47, 485-497.

Pessatti, T.B., Lüchmann, K.H., Flores-Nunes, F., Mattos, J.J., Sasaki, S.T., Taniguchi, S., Bícego, M.C., Dias Bainy, A.C., 2016. Upregulation of biotransformation genes in gills of oyster Crassostrea brasiliana exposed in situ to urban effluents, Florianópolis Bay, Southern Brazil. Ecotoxicol. Environ. Saf. 131:172-180. https://doi.org/10.1016/j. ecoenv.2016.04.003.

Pires, A., Almeida, Â., Calisto, V., Schneider, R.J., Esteves, V.I., Wrona, F.J., Soares, A.M.V.M., Figueira, E., Freitas, R., 2016a. Hediste diversicolor as bioindicator of pharmaceutical pollution: Results from single and combined exposure to carbamazepine and caffeine. Comp. Biochem. Physiol. Part C 188:30-38. https://doi.org/10.1016/j. cbpc.2016.06.003.

Pires, Almeida A., Correia, J., Calisto, V., Schneider, R.J., Esteves, V.I., Soares, A.M.V.M. Figueira, E., Freitas, R., 2016b. Long-term exposure to caffeine and carbamazepine: impacts on the regenerative capacity of the polychaete Diopatra neapolitana. Chemosphere 146:565-573. https://doi.org/10.1016/..chemosphere.2015.12.035.

Prabhu, K.S., Reddy, P.V., Jones, E.C., Liken, A.D., Reddy, C.C., 2004. Characterization of a class alpha glutathione-S-transferase with glutathione peroxidase activity in human liver microsomes. Arch. Biochem. Biophys. 424:72-80. https://doi.org/10.1016/j. abb.2004.02.002.

Rabii, F.W., Segura, P.A., Fayad, P.B., Sauvé, S., 2014. Determination of six chemotherapeutic agents in municipal wastewater using online solid-phase extraction coupled to liquid chromatography-tandem mass spectrometry. Sci. Total Environ. $487,792-800$.
Royse, C.F., 1970. An Introduction to Sediment Analysis. Arizona State University, Tempe, AZ

Santos, M.A., Pacheco, M., 1995. Mutagenicity of cyclophosphamide and kraft mill effluent and sediment on the eel Anguilla anguilla L. 171, 0-3.

Seira, J., Sablayrolles, C., Montréjaud-Vignoles, M., Albasi, C., Joannis-Cassan, C., 2016. Elimination of an anticancer drug (cyclophosphamide) by a membrane bioreactor: comprehensive study of mechanisms. Biochem. Eng. J. 114:155-163. https://doi. org/10.1016/j.bej.2016.07.001.

Shakil, S., Khan, R., Tabre, S., Alam, Q., Nasimudeen, R.J., Sulaiman, M., Greig, N.H., Kamal, M.A., 2011. Interaction of human brain acetylcholinesterase with cyclophosphamide: a molecular modeling and docking study. CNS Neurol. Disord. Drug Targets 10: 845-848. https://doi.org/10.1038/nbt.3121.ChIP-nexus.

Singh, N.P., McCoy, M.T., Tice, R.R., Schneider, E.L., 1988. A simple technique for quantitation of low levels of DNA damage in individual cells. Exp. Cell Res. 175, 184-191.

Singh, M., Kumar, N., Shuaib, M., Garg, V.K., 2014. A review on renal protective agents for cyclophosphamide induced nephrotoxicity. World J. Pharm. Pharm. Sci. 3, 737-747.

Sivadas, S., Ingole, B., Nanajkar, M., 2010. Benthic polychaetes as good indicators of anthropogenic impact. Indian J. Mar. Sci. 39, 201-211.

Solé, M., Kopecka-Pilarczyk, J., Blasco, J., 2009. Pollution biomarkers in two estuarine invertebrates, Nereis diversicolor and Scrobicularia plana, from a Marsh ecosystem in SW Spain. Environ. Int. 35:523-531. https://doi.org/10.1016/j.envint.2008.09.013.

Steger-Hartmann, T., Kümmerer, K., Schecker. J., 1996. Trace Analysis of the Antineoplastics Ifosfamide and Cyclophosphamide in Sewage Water By Two-step Solid-phase Extraction and Gas Chromatography-Mass Spectrometry. p. 9673.

Steger-Hartmann, T., Kümmerer, K., Hatmann, A., 1997. Biological degradation of cyclophosphamide and its occurrence in sewage water. Ecotoxicol. Environ. Saf. 36: 174-179. https://doi.org/10.1006/eesa.1996.1506.

Sulkowska, M., Sulkowski, S., Skrzydlewska, E., Farbiszewski, R., 1998 Cyclophosphamide-induced Generation of Reactive Oxygen Species. Comparison With Morphological Changes in Type II Alveolar Epithelial Cells and Lung Capillaries,

Sun, F., Zhou, Q., 2008. Oxidative stress biomarkers of the polychaete Nereis diversicolor exposed to cadmium and petroleum hydrocarbons. Ecotoxicol. Environ. Saf. 70: 106-114. https://doi.org/10.1016/j.ecoenv.2007.04.014.

Sun, L., Shao, X., Hu, X., Chi, J., Jin, Y., Ye, W., Fu, Z., 2011. Transcriptional responses in Japanese medaka (Oryzias latipes) exposed to binary mixtures of an estrogen and anti-estrogens. Aquat. Toxicol. 105:629-639. https://doi.org/10.1016/j. aquatox.2011.08.024.

Ternes, T.S., 1998. Occurrence of drugs in German sewage treatment plants and rivers. Water Res. 32:3245-3260. https://doi.org/10.1016/S0043-1354(98)00099-2.

Thain, J., Bifield, S., 2001. Biological effects of contaminants: sediment bioassay using the polychaete Arenicola marina. ICES Tech. Mar. Environ. Sci. 29 (ISSN 0903-2606).

Thomas, K.V., Dye, C., Schlabach, M., Langford, K.H., 2007. Source to sink tracking of selected human pharmaceuticals from two Oslo city hospitals and a wastewater treatment works. J. Environ. Monit. 9:1410-1418. https://doi.org/10.1039/b709745j.

Trombini, C., Fonseca, T.G., Morais, M., Lopes, T., Blasco, J., Bebianno, M.J., 2016. Toxic effects of cisplatin cytostatic drug in mussel Mytilus galloprovincialis. Mar. Environ. Res. 119, 12-21.

Usawanuwat, J., Boontanon, N., Boontanon, S.K., 2014. Analysis of three anticancer drugs (5-fluorouracil, cyclophosphamide and hydroxyurea) in water samples by HPLC-MS, MS. Int. J. Adv. Agric. Environ. Eng. 1, 72-76.

Valasani, K.R., Chaney, M.O., Day, V.W., Shidu Yan, S., 2013. Acetylcholinesterase inhibitors: structure based design, synthesis, pharmacophore modeling, and virtual screening. J. Chem. Inf. Model. 53:2033-2046. https://doi.org/10.1021/ci400196z.

Valcárcel, Y., Alonso, S.G., Rodríguez-gil, J.L., Gil, A., Catalá, M., 2011. Detection of pharmaceutically active compounds in the rivers and tap water of the Madrid Region (Spain) and potential ecotoxicological risk. Chemosphere 84:1336-1348. https://doi.org/ 10.1016/j.chemosphere.2011.05.014

Van Wijk, R., Tans, S.J., ten Wolde, P.R., Mashaghi, A., 2015. Non-monotonic dynamics and crosstalk in signaling pathways and their implications for pharmacology. Sci. Rep. 5 : 1-13. https://doi.org/10.1038/srep11376.

Vethaak, A.D., Hamers, T., De Weert, J., Kamstra, J.H., Leonards, P.E.G., Smedes, F., 2016 Toxicity profiling of marine surface sediments: a case study using rapid screening bioassays of exhaustive total extracts, elutriates and passive sampler extracts. Mar. Environ. Res. 1-11.

Vyas, N., Turner, A., Sewell, G., 2014. Platinum-based anticancer drugs in waste waters of a major UK hospital and predicted concentrations in recipient surface waters. 493 324-329.

Williams, D.C., Carroll, B.J., Jin, Q., Rithner, C.D., Lenger, S.R., Floss, H.G., Coates, R.M., Williams, R.M., Croteau, R., 2000. Intramolecular proton transfer in the cyclization of geranylgeranyl diphosphate to the taxadiene precursor of taxol catalyzed by recombinant taxadiene synthase. Chem. Biol. 7:969-977. https://doi.org/10.1016/ S1074-5521(00)00046-6.

Winckler, K., Madle, S., Nau, H., 1984. Mutagenic activities of cyclophospamide (NSC26271) and its main metabolites in Salmonella typhimurium, human peripheral lymphocytes and Chinese hamster ovary cells. Mutat. Res. 129, 47-55.

Winter, M.J., Ellis, L.C.J., Hutchinson, T.H., 2007. Formation of micronuclei in erythrocytes of the fathead minnow (Pimephales promelas) after acute treatment with mitomycin C or cyclophosphamide. Mutat. Res. 629:89-99. https://doi.org/10.1016/j. mrgentox.2007.01.010

World Health Organization, 2014. Global Status Report On Noncommunicable Diseases. p. 2014.

Xie, H., 2012. Occurrence, ecotoxicology, and treatment of anticancer agents as water contaminants. J. Environ. Anal Toxicol. https://doi.org/10.4172/2161-0525.S2-002.

Yasunaga, K., Kiyonari, A., Nakagawa, M., Yoshikawa, K., 2006. Investigation into the ability of the Salmonella umu test to detect DNA damage using antitumor drugs. Toxicol. in Vitro 20:712-728. https://doi.org/10.1016/j.tiv.2005.10.007. 
Yin, J., Shao, B., Zhang, J., Li, K., 2010. A preliminary study on the occurrence of cytostatic drugs in hospital effluents in Beijing, China. Bull. Environ. Contam. Toxicol. 84:39-45. https://doi.org/10.1007/s00128-009-9884-4.

Yu, J.T., Bouwer, E.J., Coelhan, M., 2006. Occurrence and biodegradability studies of selected pharmaceuticals and personal care products in sewage effluent. Agric. Water Manag. 86:72-80. https://doi.org/10.1016/j.agwat.2006.06.015.

Zounková, R., Odráska, P., Dolezalová, L., Hilscherová, K., Marsálek, B., Bláha, L., 2007. Ecotoxicity and genotoxicity assessment of cytostatic pharmaceuticals. Environ. Toxicol. Chem. 26:2208-2214. https://doi.org/10.1897/07-137R.1.
Zuccato, E., Calamari, D., Natangelo, M., Fanelli, R., 2000. Presence of therapeutic drugs in the environment for personal use. Lancet 355, 1789-1790.

Zuccato, E., Castiglioni, S., Fanelli, R., 2005. Identification of the pharmaceuticals for human use contaminating the Italian aquatic environment. J. Hazard. Mater. 122: 205-209. https://doi.org/10.1016/j.jhazmat.2005.03.001. 